\title{
NASTAVA GLAZBE U HRVATSKIM OPĆEOBRAZOVNIM SREDNJIM ŠKOLAMA
}

\author{
Ivana Senjan \\ Gimnazija dr. Ivana Kranjčeva, \\ Đurđevac, Hrvatska \\ ivana.senjan1@gmail.com
}

\begin{abstract}
Pedagoške reforme u Hrvatskoj i svijetu posljednjih dvadesetak godina ukazale su na potrebu za usklađivanjem obrazovnoga sustava sa suvremenim obrazovnim potrebama i izazovima stavljajući učenika $u$ središte nastavnoga procesa. Unatoč sugestijama brojnih glazbenih pedagoga u smjeru unaprijeđivanja i mijenjanja postojećih pristupa u nastavi, nastava se glazbe na srednjoškolskoj razini u Hrvatskoj još od školske godine 1954./1955. odvija po istom dijakronijskom modelu koji se temelji na kronološkoj obradi povijesti glazbe, što dovodi do sraza između tradicionalno koncipiranoga nastavnog modela i suvremenih obrazovnih nastojanja. Ovaj rad ističe važnost nastave glazbe za estetski odgoj i razvoj glazbene kulture učenika, objedinjuje opća obilježja nastavnog predmeta Glazbena umjetnost te prikazuje njegovu retrospektivu, trenutnu situaciju i aktualnu problematiku u nastavi. $S$ ciljem efektivnijeg glazbenog obrazovanja učenika srednjoškolske populacije, predlaže se suvremeniji pristup poučavanju koji bi se temeljio na spoju znanstvenih istraživanja i praktičnih iskustava nastavnika glazbe bez kojih ipak nije moguće ostvarivati bitne pomake u razvoju glazbene pedagogije kao znanosti.
\end{abstract}

Ključne riječi: estetski odgoj, glazbena kultura, Glazbena umjetnost, glazbeni ukus, modeli poučavanja glazbe

\section{Uvod}

Nastava glazbe sastavni je dio općeobrazovnih programa s ciljem razvoja i oblikovanja kulturnog identiteta koji pridonosi kvaliteti osobnog i društvenog življenja. Temelji se na estetskom odgoju kroz upoznavanje, razumijevanje, kritičko vrednovanje i prihvaćanje estetski 
vrijedne glazbe te na stjecanju znanja o općim obilježjima glazbene umjetnosti kroz povijest. Učinkovitost estetskog odgoja današnje djece i mladeži u općeobrazovnim osnovnim i srednjim školama propituju brojni domaći i inozemni znanstvenici. ${ }^{1}$ Oni sugeriraju reorganizaciju nastavnih sadržaja uz suvremeniji pristup koji u obzir uzima brojne čimbenike koji utječu na glazbeno-kulturni razvoj učenika (obitelj, društvo, mediji, suvremena tehnologija i dostupnost informacija...). Pomaci prema pedagoškom i didaktičkom pluralizmu vidljiviji su od uvođenja Hrvatskog nacionalnog obrazovnog standarda (HNOS, 2006), obnovljenog Nastavnog plana i programa za osnovno školstvo (2006) i Nacionalnog okvirnog kurikuluma (NOK, 2011). Pomak je vidljiv i u općim smjernicama Prijedloga Nacionalnog kurikuluma nastavnog predmeta Glazbena kultura i Glazbena umjetnost (2016) koji je proizašao iz Cjelovite kurikularne reforme. Aktualna glazbeno-pedagoška promišljanja ukazuju na nužno senzibiliziranje nositelja odgoja i obrazovanja za promjene (Matijević i Rajić, 2015, 638) i unapređivanje postojećih pristupa u nastavi s ciljem otvorene i kreativne nastave. Takva bi nastava podrazumijevala suvremena didaktička i metodička rješenja usmjerena prema kompetencijama i preferencijama novih generacija učenika (Škojo, 2016, 247). Prema tome, organizacija nastave glazbe trebala bi proizlaziti iz aktivnosti slušanja i analize glazbenih djela uz interdisciplinarni pristup. Uz upoznavanje umjetničke glazbe, veći udio u nastavnim programima trebao bi se posvetiti upoznavanju reprezentativnih primjera popularne i tradicijske glazbe s ciljem razumijevanja i prihvaćanja kvalitetnih glazbenih izričaja te samostalnog otkrivanja i slušanja vrijedne glazbe u svakodnevnom životu.

Glazbeno obrazovanje u Hrvatskoj obvezatni je dio kurikuluma osnovne i općeobrazovne srednje škole, prisutno je u pojedinim programima strukovnog usmjerenja, a usmjereno glazbeno obrazovanje moguće je u osnovnoj i srednjoj glazbenoj školi te na visokoobrazovnim institucijama (Sveučilište u Zagrebu: Muzička akademija te Katolički bogoslovni fakultet: Institut za crkvenu glazbu, Sveučilište J. Dobrile u Puli, Sveučilište u Splitu i Sveučilište J. J. Strossmayera u Osijeku) koje nude različite programe studija glazbe ili glazbenog obrazovanja u okviru studija predškolskog odgoja i razredne nastave (Učiteljska akademija u Zagrebu, Osijeku, Rijeci, Splitu, Petrinji, Čakovcu, Zadru).

${ }^{1}$ Dobrota, S., Duraković, L., Elliott, D., Hargreaves, D., Harland, J., Lamont, A., North, A., Reimer, B., Rojko, P., Ross, M., Svalina, V., Škojo, T., Šimunović, Z., Šulentić Begić, J., Vidulin, S. i drugi. 
Nastava Glazbene kulture u osnovnoj školi i nastava Glazbene umjetnosti u srednjoškolskom obrazovanju pripadaju umjetničkom području (uz Vizualne umjetnosti i dizajn, Filmsku i medijsku kulturu i umjetnost, Dramsku kulturu i umjetnost). Svrha je tog područja, prema Nacionalnom okvirnom kurikulumu (MZOS, 2011, 208), osposobiti učenike za učenje i razumijevanje različitih vrsta umjetnosti kako bi mogli što bolje razumjeti sebe i svijet pomoću umjetničkih djela i medija, ali i izraziti svoje osjećaje, iskustva, ideje i stavove umjetničkim aktivnostima i stvaralaštvom. S ciljem uvođenja u glazbenu, a time i opću kulturu, nastava glazbe učenicima omogućuje bavljenje različitim aktivnostima. U osnovnoj školi dugi niz godina bio je prisutan integrativni model koji je objedinio glazbeno opismenjavanje, pjevanje, sviranje, improvizaciju, stvaralaštvo, slušanje glazbe i obradu muzikoloških sadržaja. Uvođenjem otvorenog modela nastave glazbe u osnovnoj školi u okviru projekta izrade Hrvatskoga nacionalnog obrazovnog standarda (HNOS) 2006. godine, slušanje i upoznavanje glazbe uvedeno je kao centralna aktivnost nastavnog sata Glazbene kulture, dok su ostale aktivnosti ostavljene na izbor samome nastavniku. U srednjoškolskom općem glazbenom obrazovanju, kao nastavku osnovnoškolskog obrazovanja, aktivno slušanje i upoznavanje glazbe također bi trebala biti glavna aktivnost nastavnoga sata. Usmjerenost na percepciju i recepciju glazbenog umjetničkog djela posebno se ističe i u Nacionalnom okvirnom kurikulumu za predškolski odgoj i obrazovanje te opće obvezno i srednjoškolsko obrazovanje (NOK), temeljnom dokumentu hrvatske obrazovne politike koji je Ministarstvo znanosti, obrazovanja i športa RH donijelo 2011. godine. No, prema aktualnom dijakronijskom modelu nastava se glazbe na srednjoškolskoj razini koncipira kao povijest glazbe, odnosno kao muzikološka obrada nastavnih sadržaja koji prate kronološki razvoj glazbe od pretpovijesti do pravaca 20. stoljeća. Upoznavanje i razumijevanje same glazbe u potpunosti se ne ostvaruje jer su nastavni programi u prvom redu zaokupljeni mnoštvom znanja $o$ glazbi, odnosno značajkama glazbenih stilova s brojnim korelacijama i detaljnim biografijama skladatelja, dok je aktivnost slušanja i analize glazbe tek na trećem mjestu (Dugandžić, 2012, 73). Takvim je pristupom uspješnost estetskog odgoja nastave Glazbene umjetnosti dovedena u pitanje, a najveći je razlog tome informativno slušanje skladbi i upoznavanje glazbe verbalnim opisivanjem glazbenih značajki. Formi zatvorenog kurikuluma nastave Glazbene umjetnosti doprinose i aktualni udžbenici koji, iako na zanimljiv način, prilično detaljno i opširno 
opisuju sadržaje određene službenim nastavnim programom. Takav način rada sputava otvoreniji pristup u poučavanju, aktivno i suradničko učenje te kvalitetnije upoznavanje glazbe koje ima velik značaj u razvoju kritičkog mišljenja potrebnog za estetski razvoj učenika. Matijević i Rajić (2015) naglašavaju da danas u nastavnim programima ima previše tema i sadržaja koji nisu zanimljivi niti potrebni pripadnicima net-generacija djece i mladih. U didaktičkoj literaturi takvo se stanje obilježava sintagmom 'historicizam u nastavi' što znači da je previše povijesnih sadržaja, a nedovoljno suvremenih tema u školskim i nastavnim kurikulumima. Isti autori također ističu da se stručnjaci ne mogu usuglasiti te su nedovoljno odlučni po pitanju tema koje bi potpuno trebalo ukloniti iz nastavnih programa, a zadržati samo one koje su potrebne kao dio opće kulture ili kao dio egzemplarnih sadržaja koji su važni za razumijevanje životno važnijih tema i stjecanje kompetencija koje će biti važne u nadolazećim godinama (Matijević i Rajić, 2015, 639).

Estetsko procjenjivanje kao osjetljivost na umjetničku kvalitetu djela ili izvođenja, glazbene preferencije kao kratkoročno sviđanje neke skladbe te glazbeni ukus kao trajnija dispozicija koja predstavlja ukupnost preferencija pojedinca (Dobrota, 2012a, 45) predmet su proučavanja brojnih znanstvenika. Njihovi rezultati mogu uvelike pridonijeti unaprjeđenju glazbene nastavne prakse jer krajnji je cilj nastave glazbe upravo estetski odgoj i razvoj glazbenog ukusa slušatelja. Brojni autori svojim istraživanjima nastoje pridonijeti unapređenju nastavne prakse, no unatoč njihovim pregnućima, u srednjoškolskom obrazovanju nastava glazbe nije omiljena ni efikasna, o čemu primjerice pišu Bray (2000), Harland (2000), Lamont i sur. (2003), Rojko (2001), Ross (1995), Škojo (2016), Škojo i Matković (2016) i drugi. Uzroci se mogu promatrati s glazbeno-pedagoškog, glazbeno-psihološkog i sociološkog aspekta u kojemu se estetske prosudbe i glazbene preferencije povezuju s osobnim stavovima učenika, društvenim ponašanjima i emocionalnim procesima. Tako Harland (2000) ističe postojanje kulturne disonance između sadržaja nastave glazbe u srednjoj školi i glazbe koju tinejdžeri slušaju izvan škole, ali i nedostatak motivacije koja je povezana sa slabom i nedovoljnom osposobljenosti glazbenih pedagoga, dok Ross (1995; 1998) naglašava činjenicu da sadržaj predmeta nije prilagođen izazovima i promjenama modernog društva u kojem učenici žive. Dobrota (2016b, 18-27) navodi istraživanja čiji rezultati ukazuju na to da učenici u školi traže glazbu sličnu onoj koju slušaju izvan škole (Ericsson, 2002; Green, 2008) i da učenici ne vide povezanost između glaz- 
be $\mathrm{u}$ »stvarnom svijetu« $\mathrm{i}$ glazbe $\mathrm{u}$ školi te se zato pokušavaju isključiti iz školske glazbe (Hanley i Roberts, 2003). Činjenica da se "glazba uvijek sluša u društvenom kontekstu, u određenom vremenu i na određenom mjestu, sa ili bez drugih pojedinaca te istovremeno s drugim aktivnostima koje imaju vlastita značenja i izvore emocija... « (Sloboda i O’Neill, 2001 u: Dobrota i Reić Ercegovac, 2016, 48) pokazuje kompleksnost ovoga područja zbog velikog broja različitih čimbenika koji utječu na estetsku percepciju i glazbene preferencije slušatelja. Dobrota i Reić Ercegovac (2016, 14-15) temeljem Interaktivne teorije glazbenih preferencija (LeBlanc, 1982) i Recipročnog modela reakcija na glazbu (Hargreaves, Miell i MacDonald, 2005) utjecajne čimbenike svrstavaju u nekoliko skupina: kognitivni, emocionalni, kulturni i društveni, fiziološka pobuđenost, ponavljanje i poznatost glazbe, karakteristike glazbe te osobine slušatelja, a navedeni čimbenici mogu biti u međusobnoj interakciji. Stoga je poznavanje utjecajnih čimbenika na glazbene preferencije slušatelja od neprocjenjive važnosti za glazbene pedagoge u svrhu osmišljavanja raznolike i zanimljive nastave glazbe koja je u skladu s učenikovim interesima, potrebama i suvremenim pedagoškim idealima.

Činjenica da je u današnjoj masmedijskoj glazbenoj okolini slušanje glazbe osnovni način glazbenog ponašanja, odgoj slušatelja i poznavatelja glazbe nameće se kao prvorazredni problem ne samo nastave glazbe nego i glazbene kulture uopće, jer je »masovna produkcija dovela na scenu dosad neviđene količine glazbenog kiča i glazbenih bezvrijednosti koje mladi svjesno i bez kritičkog stava svakodnevno konzumiraju« (Rojko 2012a, 46). Postavlja se stoga pitanje učinkovitosti nastave Glazbene umjetnosti koja u odnosu na sve utjecajne čimbenike možda i nema značajan udio u oblikovanju glazbenog ukusa učenika, no ipak ima veliku odgovornost jer može biti presudan čimbenik u formiranju kulturnog identiteta pojedinca. Zato bi glazbeni pedagozi svakako trebali pronaći odgovarajući model poučavanja za što efikasniji estetski odgoj učenika putem aktivnog i analitičkog slušanja glazbe u kojemu bi se, kroz različite suvremene oblike rada, učenike izlagalo različitim glazbenim iskustvima i promišljanjima, i to ne samo u školi nego i u privatno vrijeme. Takvim pristupom težilo bi se uspostavljanju osobnih kriterija vrednovanja glazbe ali i razvijanju interesa za različite glazbene žanrove, bez obzira radi li se o umjetničkoj, tradicijskoj ili popularnoj glazbi (Dobrota, 2012a, 37). 


\section{Estetskim odgojem do glazbene kulture učenika}

Još od samih početaka obrazovanja, škola ima zadatak poticati učenike na zanimanje za estetska obilježja umjetničkog djela i osposobljavati ih za uočavanje, doživljavanje, ostvarivanje i vrednovanje lijepog i skladnog. Potreba za umjetnošću, kao i estetski odgoj, bitan je i sastavni dio razvoja i formiranja opće kulture čovjeka. Kultura pojedine osobe predstavlja ukupnost obrazovanja, znanja, vještina, etičkih i socijalnih osjećaja, društvenog ophođenja i ponašanja (Anić i Goldstein, 2002, 759) i promatra se s nekoliko stajališta: kultura kao umjetnost $i$ umjetnička djelatnost, kultura kao način života te kultura kao proces razvoja (Baldwin i sur., 1999, 4-7). Kultura kao umjetnost koja se može očitovati kroz glazbenu kulturu pojedine osobe predstavlja uže interesno područje, a povezuje brojne aspekte opće kulture, sociologije, psihologije i muzikologije s vrijednostima u glazbi (Robinson, 2009, 9). Razvija se kroz učenje, prepoznavanje i prihvaćanje glazbeno vrijednih ostvarenja čime se javlja potreba za unaprjeđenjem duhovne, duševne i osjetilne dimenzije s ciljem intelektualno-emotivnog zadovoljstva i nadahnuća tijekom slušanja ili izvođenja glazbe.

Osobnu glazbenu kulturu pojedinac može razvijati na više načina: intrinzičnom motivacijom, pod utjecajem brojnih čimbenika (obitelj, društvo, masovni mediji, kulturni konteksti...) te kroz formalno, neformalno i informalno glazbeno obrazovanje. Promatrajući utjecaj općeg formalnog obrazovanja, uočavamo da prema pedagoškom standardu učenici trebaju ispunjavati tri vrste zadataka: materijalne, koji se odnose na usvajanje određene količine znanja i ovladavanje potrebnim umijećima, funkcionalne, koji podrazumijevaju razvijanje tjelesnih i intelektualnih sposobnosti i odgojne, koji pretpostavljaju izgradnju pozitivnih karakternih osobina na temelju općeljudskih, društvenih i osobnih vrijednosti (Vukasović, 2001, 68-71). Upravo takvom općekulturnom i općeodgojnom razvoju učenika pridonosi estetski odgoj koji u svojem fokusu promatra ljepotu, kvalitetu i smisao umjetničkog djela, a temelji se na osjetnoj percepciji, emocionalnom doživljaju, znanju te vrijednosnim kriterijima.

Termin estetika prvi je puta upotrijebio njemački filozof Alexander Gottlieb Baumgarten 1750. godine definirajući estetiku kao kritiku ukusa odnosno kao znanost osjetilne spoznaje. Estetika se, u kontekstu filozofije, odnosi na osjetilno doživljavanje i izražavanje sebe i svijeta, dok se u kontekstu umjetnosti estetika bavi pitanjima lijepog u umjet- 
nosti i umjetničkom stvaralaštvu (Dobrota i Reić Ercegovac, 2016, 10). Značaj estetskog odgoja vidljiv je i u koncepciji nastave glazbe koja se temelji na dva načela: psihološkom i kulturno-estetskom (Rojko, 2012a, 132). Psihološko načelo polazi od činjenice da učenici u pravilu vole glazbu i da se njome žele aktivno baviti, dok kulturno-estetsko načelo polazi od toga da bi se estetskim odgojem trebao razvijati i oblikovati glazbeni ukus učenika kako bi već za vrijeme ali i nakon škole postali kompetentnim korisnicima glazbene kulture. Za kritičko prosuđivanje glazbe koje je ključno za pozitivan estetski odgovor slušatelja, Supičić (2006, 49-59) ističe da se skladba mora razumjeti, što znači da ju učenik treba znati protumačiti, a protumačiti skladbu znači otkriti njezine uzroke, kvalitete i vrijednosti. Slično ističu i Mursell i Glenn $(2013,74)$ koji smatraju da je »srce« glazbenog obrazovanja razumijevanje glazbe, koje definiraju kao iskustvo povezano s ljepotom i snagom glazbe. Elliot i Silvermann $(2015,381)$ u svojoj praksijalnoj filozofiji glazbenog obrazovanja opisuju razumijevanje glazbenih vrijednosti tijekom slušanja kao formu mišljenja i znanja, ali i kao izvor samorazvoja i samopostojanja slušatelja čije će uživanje u slušanju, kao i samorazvoj, ovisiti o ravnoteži slušateljevih glazbenih sposobnosti (npr. od slušatelja početnika do slušatelja eksperta) i glazbenih izazova (npr. od bezvoljnosti i frustracije preko uživanja do dosade za vrijeme slušanja). Autori naglašavaju da će najveće iskustvo slušanja i zadovoljstva nastupiti kada se izjednači razina glazbenog razumijevanja s ukupnim izazovom koji će potom uzrokovati razumijevanje slušane izvedbe i slušateljev doživljaj u vidu sreće ili ugode. Sukladno tome, Berlyne (Berlyne, 1974 u: Dobrota i Reić Ercegovac, 2016, 10-13) također polazi od pretpostavke da karakteristike umjetničkog djela, poput složenosti, novosti, nesigurnosti i konflikta, izazivaju razine pobuđenosti te da postoji optimalna kombinacija takvih osobina koja kod ljudi izaziva estetski doživljaj. Kvaliteta tog doživljaja i iskustva ovisi i o sposobnosti slušatelja za intenzitet doživljaja $\mathrm{i}$ iskustva koje treba povezivati s duhovnom, estetskom i ekspresivnom kvalitetom glazbe jer: »isključivo ona glazba koja je ne samo osjetno percipirana nego i duhom shvaćena prema glazbenoj spoznatljivosti koju sadrži u sebi i za slušatelja može biti kvalificirana kao potpuno doživljena« (Supičić, 2006, 302).

Iako postoje brojni pristupi analizi glazbenog djela, uz aktivno slušanje i formalnu analizu, osnova razumijevanja neke skladbe je estetski interes bez kojeg učenik ne može biti otvoren za doživljaj umjetnosti i, konačno, preferencije slušane skladbe. Slijedom toga, Dykema i 
Gehrkens $(2013,73)$ smatraju da bi nastavnici trebali znati pobuditi interes učenika za glazbu kako bi ih vodili kroz slušanje, ali na način da ne dominiraju svojim stavovima kako bi učenici mogli nenametljivo uživati u slušanju i lakše osjetiti povezanost s glazbom. U tome mogu pomoći neka od novijih istraživanja koja područje glazbene estetike sagledavaju iz interdisciplinarnog rakursa, povezujući estetiku glazbe ne samo s muzikologijom, filozofijom, povijesti i umjetničkom kritikom, već i s područjem psihologije, fiziologije i sociologije. Tako Madden (2014, 22-25) ističe biološki određeni faktor utjecaja na estetski odgovor slušatelja glazbe koji ovisi o intenzitetu otpuštanja dopamina u mozgu koji uvjetuju primarne evolucijske potrebe kao što su primjerice hrana ili fiziološka uzbuđenost. Istraživanja u neuroznanosti pokazuju da odgovor slušatelja na glazbu nije samo radost i ushićenje, strah ili bijes (pozitivna ili negativna valencija), već uživanje i traženje zadovoljstva koje se primarno povezuje s razinom intenziteta emocije. Vidulin-Orbanić (2008) također ističe da dijete glazbeno djelo doživljava najprije fiziološki i emocionalno jer je za njega u trenutku slušanja ili muziciranja važno da se osjeća lijepo. Zato je jedan od najvažnijih zadataka estetskog odgoja naučiti učenike kako da prvotni doživljaj neke skladbe, temeljem odgovarajuće razine pobuđenosti, izazova, pozitivne emocije i raspoloženja te glazbenog razumijevanja, preraste u glazbeno-estetski doživljaj.

Pojedini glazbeni pedagozi smatraju da popularna glazba ne bi trebala biti zastupljena u nastavnim programima iz razloga što »učenike nije potrebno učiti njihovoj glazbi jer ju oni uzimaju onakvom kakva ona jest i u tome im nije potrebna nikakva metodička pomoć« (Rojko, $2005,10)$. No pritom se postavljaju sljedeća pitanja: Koja je to njiho$v a$ glazba i kakve je ona estetske vrijednosti? Prema kojim kriterijima učenici preferiraju svoju glazbu? Je li ta glazba uistinu najbolje od onog što učenici odabiru od svekolike ponude glazbenih sadržaja u nastavi glazbe i svakodnevici?, i konačno, Koja je stvarna razina glazbene kulture učenika čijem se razvoju toliko teži upravo glazbenim obrazovanjem u osnovnoj i srednjoj školi? Očito je da u današnje doba, kada je izbor i kvaliteta glazbenih sadržaja iznimno velika i raznolika, učenici pod najvećim utjecajem medija i vršnjaka često preferiraju popularnu glazbu upitne estetske vrijednosti, dok prema umjetničkoj ili kvalitetnoj glazbi nemaju razvijen interes. Iako bi trendovi u glazbenom obrazovanju trebali pratiti društvena kretanja s ciljem razvoja kritičkog mišljenja, sadržaji suvremenih školskih programa uglavnom ne odražavaju 
glazbeni svijet u kojemu živimo. Na primjer, u hrvatskoj je nastavnoj praksi ustaljen rad prema izvedbenim nastavnim programima Glazbene umjetnosti izdavačke kuće Profil Klett koji prate službene udžbenike Glazbene umjetnosti za četverogodišnji gimnazijski program (Perak Lovričević i Ščedrov, Glazbeni susreti 1., 2., 3., i 4. vrste). Prema njima su nastavne jedinice poput jazz glazbe, mjuzikla i pravaca rock glazbe, za koje učenici inače pokazuju prilično veliki interes, zastupljene tek pred završetak četvrtoga razreda. Tako je na izbor nastavniku ponuđeno 25 skladbi koje se informativno slušaju tijekom svega sedam od ukupno 137 nastavnih sati četverogodišnjeg gimnazijskog programa. Prije četvrtog razreda, jedino je još u prvome razredu prilikom obrade glazbeno-izražajnih sastavnica moguće slušanje maksimalno osam brojeva popularne glazbe i to iz razdoblja 70 -ih godina 20 . stoljeća, pet brojeva iz područja mjuzikla, jazz i filmske glazbe te pet brojeva tradicijske glazbe. U drugom, trećem i većem dijelu četvrtog razreda ne postoji predviđen niti jedan primjer ostalih vrsta glazbe osim umjetničke čija su obilježja stilski određena za svaki razred (u 1. razredu glazba srednjeg vijeka i renesanse, u 2. razredu glazba baroka i klasike, u 3. razredu glazba romantizma). Obrada tradicijske glazbe Hrvatske i svijeta koju nude aktualni udžbenici moguća je jedino u prvome razredu, no njezina provedba ipak ovisi o afinitetu nastavnika jer u Prijedlogu izvedbenog nastavnog programa za prvi razred nije predviđen niti jedan sat. Tako u kontekstu obrade tradicijske glazbe, Robinson $(2009,40)$ ističe da u kurikulumu glazbenog obrazovanja diljem svijeta zbog utjecaja etnomuzikologije i globalizacije dolazi do inkluzije različitih glazbenih kultura koje ne pripadaju umjetničkoj glazbi zapadne tradicije, odnosno dolazi do uvođenja interkulturalnog glazbenog obrazovanja. Razlog tome je što se želi izbjeći ustaljena praksa hijerarhijskog odnosa između glazbenih stilova i naglasiti važnost društvenog konteksta u kojem se nalaze učenici. Iako popularna glazba, kao uostalom ni tradicijska, ne mogu imati primat u nastavi glazbe da se ne bi umanjila važnost i prisutnost reprezentativnih glazbenih ostvarenja umjetničke glazbe kroz povijest, suvremena glazbena pedagogija ipak upozorava na potrebu uvođenja glazbe svih razdoblja, stilova, formi i kultura u nastavni program. U skladu s takvim sugestijama, Choate je već krajem šezdesetih godina 20. stoljeća naglasio da bi u repertoar nastave glazbe ipak trebalo uključiti i »glazbu našeg vremena poput popularne tinejdžerske i avangardne glazbe, jazza, tradicijske glazbe i glazbe svijeta, ali isto tako klasične glazbe ostalih dijelova svijeta, a ne samo zapadne tradicije« (Choate, 
1967, u: Dobrota, 2012, 72). Iako današnja nastava Glazbene umjetnosti ima predviđene i takve nastavne jedinice, one ipak nisu proporcionalno zastupljene tijekom svih četiriju godina, a predviđeni izbor skladbi, na primjer popularne glazbe, zaključuje se s razdobljem 80-ih godina 20. stoljeća čiji glazbeni izričaj ipak nije toliko blizak današnjem učeniku. Takvom zatvorenom koncepcijom nastavnog programa onemogućuje se uvid u nova područja estetski vrijedne suvremene glazbe koja bi mogla postati izbor slušanja u slobodno vrijeme učenika, čime bi nastava glazbe zasigurno postala zanimljivija i bliža današnjem učeniku. Praksa pokazuje da otvorenijoj koncepciji nastavnog programa teže i sami učenici, no dominantno povijesni pristup koji se temelji na obradi kronološkog redoslijeda stilskih razdoblja i brojnih činjenica $o$ glazbi umanjuje mogućnost slušnog upoznavanja i razumijevanja same glazbe te rješavanja aktualnog problema kvalitete glazbene kulture učenika. Na taj način nastava Glazbene umjetnosti posljedično gubi na značaju, ali i na učinkovitosti estetskog odgoja.

\section{Retrospektiva nastave glazbe u hrvatskom srednjem školstvu}

Povijesni razvoj nastave glazbe u Hrvatskoj pratio je razvoj školstva koji je tijekom stoljeća ovisio o utjecaju Crkve, pedagoškim nastojanjima ili društveno-političkoj situaciji. Franković i Kujundžić smatraju da se početak organiziranog školstva u Hrvatskoj u kojem je bilo predviđeno i glazbeno obrazovanje veže uz dalmatinskog kneza Trpimira i 9. stoljeće. Naime, u Trpimirovoj darovnici iz 852. godine vidljivo je da je knez Trpimir zajedno s jednim od najobrazovanijih ljudi onoga vremena Gottschalkom Saksonskim u okvirima benediktinskog samostana u Rižinicama utemeljio prvu školu s trivijalnim i kvadrivijalnim programom (Franković, 1958, Kujundžić, 1996, u: Munjiza, 2006, 45-46). U trivijalnim školama učila se gramatika, retorika i dijalektika, a u kvadrivijalnim aritmetika, astronomija, geometrija i glazba. U daljnjem je periodu pjevanje crkvenih pjesama bilo sastavnim dijelom crkvenih škola (župne, samostanske i katedralne) koje su u Hrvatskoj organizirali benediktinci, dominikanci, franjevci, isusovci i pavlini. Obrazovanju i odgoju ženske mladeži u to su doba uvelike doprinijele sestre milosrdnice, klarise i uršulinke. Sustavnije školstvo u Hrvatskoj organizirali su isusovci 1599. godine kada je stupio na snagu nastavni plan i program po kojemu su djelovale sve isusovačke škole u 
svijetu, pa tako i u Hrvatskoj. Postojale su niže i više škole. Niže škole nosile su naziv latinske i bile su slične gimnazijama, dok su više škole nosile naziv akademije i na njima su se izučavale filozofija i teologija. Osim crkvenih škola, u Hrvatskoj su od 10. stoljeća djelovale i javne gradske škole nastale razvojem građanske klase (Klaić, 1925, u: Munjiza, 2006, 50) te državne škole čije je ozbiljnije uređivanje s jedinstvenim nastavnim planom i programom počelo za vrijeme vladavine carice Marije Terezije (1740.-1780.) donošenjem Općeg školskog reda 1774. godine i novog školskog reda Ratio educationis 1777. godine. Tijekom razvoja organiziranog hrvatskog školstva od 9. do 19. stoljeća u odgojnim načelima crkvenih i svjetovnih škola bilo je prisutno bavljenje umjetnošću koje je u području pjevanja često puta rezultiralo i sudjelovanjem učenika na javnim nastupima, priredbama i svečanostima.

Godine 1849. izrađena je osnova za organizaciju austrijskih gimnazija i realka koja je bila propisana i za hrvatske gimnazije. Batinić $(2003,55)$ opisuje da je gimnazija tada trajala osam godina od kojih su četiri niža razreda činila malu ili nižu gimnaziju. Niža gimnazija osposobljavala je učenike za prijelaz u višu gimnaziju ili neku drugu srednju školu, a viša za upis na sveučilište. Nakon završetka osmogodišnje gimnazije polagao se ispit zrelosti. Realke su u početku pružale širu izobrazbu u realnim predmetima te su trajale dvije do tri godine (male realke). Pjevanje je tada bilo sastavni dio općeg obrazovanja u gimnazijama i realkama, a nastavni predmet Gesang može se vidjeti u nastavnom programu realne gimnazije u Zagrebu iz 1854. godine (Rojko, 2012, 14). Godine 1869. realke postaju četverogodišnje, odnosno sedmogodišnje škole (više realke) i time su se po svojem programu približile gimnaziji. Nakon reorganizacije realki 1894. godine, pretvaraju se u osmorazredne realne gimnazije nakon kojih je također moguć upis na sveučilište.

Uvođenjem prvoga hrvatskoga zakona o obveznom obrazovanju 1874. godine (Zakon o pučkim školama i preparandijama u kraljevinama Hrvatskoj i Slavoniji) nastava glazbe pod nazivom Pjevanje ulazi u opće pučke škole, programe srednjih škola i tzv. preparandije u kojima su se obrazovali budući učitelji u pučkim školama (Gaćina Škalamera, 2014, 109). Iz tog perioda datiraju dvije pjesmarice za srednje škole: Vijenac (1890?) i Crkvene pjesme (1892). Osim pjevanja crkvenih i narodnih pjesama (Vidulin-Orbanić i Duraković, 2012, 6), u nastavi se također učilo i glazbeno opismenjavanje te povremeno elementi povijesti glazbe, glazbena estetika i glazbena teorija. Kvaliteta nastave 
ovisila je o osposobljenosti učitelja koji je nerijetko poučavao i dva predmeta, dok je satnica bila od pola do jednog i vrlo rijetko dva sata tjedno. Početkom 20. stoljeća srednjoškolski je sustav obrazovanja u Hrvatskoj i Slavoniji bio strukturiran od raznolikih tipova i vrsta škola - od nižih i srednjih stručnih škola (među njima su bile i umjetničke, odnosno glazbene škole) te učiteljskih škola do općeobrazovnih srednjih škola - gimnazija. Gaćina Škalamera $(2014,87)$ ističe da je ovako ustrojen srednjoškolski sustav opstajao uz neznatne izmjene do polovine 20. stoljeća te da zakonska regulativa za srednje školstvo nije bila jedinstvena, već je rad pojedinih vrsta škola bio reguliran posebnim zakonskim propisima. Tako se do Drugoga svjetskoga rata srednjoškolska nastava glazbe nazivala Pjevanje, a ponegdje i Muzika ili Glazba te je bila prisutna s dva sata tjedno u prvim dvama razredima realne i klasične gimnazije, što odgovara današnjem petom i šestom razredu osnovne škole. Također, izvodila se i u građanskim školama (zanatsko-industrijskim, trgovinskim i poljoprivrednim) sa satnicom od jednog sata tjedno tijekom prvih dviju godina. Nastavni program je uz aktivnost pjevanja težio i glazbenom stručnom osposobljavanju, točnije, učenju solfeggia i teorije glazbe, što je nastavu odvodilo u formalizam. Napamet se učila teorija bez pripadnih slušnih predodžaba i pojmova, a pjesme su se pjevale po sluhu. Poseban značaj davao se i narodnoj pjesmi te korelaciji s drugim predmetima, no unatoč slabijim rezultatima u nastavi, Rojko ističe da je, prema izvještajima o radu srednjih škola, dosta bila razvijena zborska aktivnost, a neki zborovi bili su i prvoklasni (Rojko, 2012, 15-16, u: Rakijaš, 1958, 2). Udžbenici koji su se u tom razdoblju koristili bili su Elementarna teorija muzike i pjevanja za niže razrede srednjih i njima sličnih škola (Špoljar, 1927), Elementarna teorija muzike $i$ pjevanja za pripravni tečaj Kraljevske muzičke akademije zagrebačke ( $i$ za srednje škole) (Lučić, 1927) i Elementarna teorija glazbe i pjevanja za srednje škole i početnički tečaj glazbenih škola (Lučić, 1940).

Od 1944. do 1950. godine gotovo svake školske godine donosili su se novi nastavni programi nastave glazbe za gimnaziju koja je tada imala osam razreda, pri čemu su prva četiri bila analogna današnjim višim razredima osnovne škole (niža gimnazija). Nastava glazbe odvijala se pod nazivom Pjevanje ili Pjevanje i povijest muzike, a sadržaj je obuhvaćao pjevanje, solfeggio te kronološki prikaz povijesti glazbe u višim razredima gimnazije (viša gimnazija). Satnica je bila različito raspoređena na dva ili jedan sat tjedno tijekom ukupno šest ili sedam godina učenja, no školske godine 1947./48. došlo je do drastičnog smanjenja satnice 
u višoj gimnaziji kada se nastava glazbe učila u samo prva dva razreda gimnazije s dva sata tjedno. Opseg nastavnog programa tada je ostao isti, što je postavilo nerealna očekivanja $u$ realizaciji sadržaja tadašnje nastave glazbe koja je proizlazila iz struke (npr. glazbeno opismenjavanje i rad na intonaciji). Udžbenici koji su se koristili u tom periodu bili su $\mathrm{Mu}$ zička početnica za prvi razred srednjih škola (izradio Redakcioni odbor, 1947), Muzička vježbenica za prvi razred gimnazije i peti razred sedmogodišnje škole (Antonić, Senečić i Šir, 1947) te Muzička vježbenica za drugi razred gimnazije i šesti razred sedmogodišnje škole (Antonić, Senečić i Šir, 1947). U Nastavnom planu i programu za osmogodišnje škole i niže razrede gimnazije, osnovne škole i produžne tečajeve iz 1950. godine po prvi puta se dao značaj slušanju glazbe (Rojko, 2012, 18), no opremljenost škole gramofonom ili radijom tada je još uvijek bila na neznatnoj razini. Donošenjem Zakona o narodnim školama 1951. godine postupno je uvedeno obvezatno osmogodišnje obrazovanje koje je u potpunosti zaživjelo tek nakon 1958. godine i to po modelu četiri razreda razredne nastave i četiri razreda predmetne nastave (Munjiza i Lukaš, 2006, 362) nakon kojega se srednjoškolsko obrazovanje moglo nastaviti u stručnim školama i gimnazijama (Batinić, 2003, 52). U tom procesu dokidanja osmogodišnje gimnazije, niži razredi gimnazije postali su viši razredi osnovnoškolskog obrazovanja, dok su viši razredi gimnazije postali četverogodišnja srednja škola. U školskoj godini 1954./55. donesen je i službeni plan i program nastave glazbe u gimnaziji kojoj je pripao jedan sat tjedno kroz sve četiri godine učenja, a nastavni sadržaj obrađivao se prema kronološkom pregledu povijesti glazbe koji je ostao sve do danas (Škojo, 2015a, 49). Udžbenici koji su se koristili u tom razdoblju bili su Muzička umjetnost za 1.-4. razred gimnazije (Završki, J. i sur., 1968) i Glazbena umjetnost, udžbenik za gimnazije (Završki, Njirić, Manasteriotti i Županović, 1972) koji je doživio čak devet nepromijenjenih izdanja, te Upoznavanje s glazbenim djelom, uvodna skripta iz glazbene umjetnosti za 1. i 2. razred gimnazije (Čelar, 1972).

Nova osnova reforme srednjoškolske izobrazbe donesena je Rezolucijom X. kongresa Saveza komunista Jugoslavije (SKJ) o odgoju i obrazovanju 1974. godine, nakon čega je došlo do ukidanja gimnazija i osnivanja Centra za odgoj i usmjereno obrazovanje (COUO, CUO). Srednjoškolsko se obrazovanje tada organiziralo u pripremnom (zajedničke osnove nastavnog plana i programa) i završnom stupnju (usmjerenje), a u reformiranu srednju školu prvi je naraštaj krenuo u šk. god. 1975./76. Ipak, nakon brojnih kritika, Zakonom o usmjerenom obrazo- 
vanju iz 1982. godine napustila se koncepcija pripremnog i završnog stupnja te se utvrdilo usmjeravanje u struku od samog početka srednje izobrazbe (Batinić, 2003, 57). Prema Okvirnom obrazovnom programu sadržaja struke u prvoj i drugoj godini usmjerenog obrazovanja (1984, 1985, 1986) nastava glazbe se u većini struka (npr. ekonomska, trgovinska, upravno-pravna, poljoprivredna, veterinarska...) poučavala u okviru opće naobrazbe kroz prve dvije godine učenja i to pod nazivom Likovna i glazbena kultura. Umjetničko odgojno-obrazovno područje objedinilo je zajedničku satnicu likovne i glazbene kulture koja je iznosila ukupno 34 sata u prvome $\mathrm{i}$ isto toliko u drugome razredu, odnosno 68 sati za obje godine učenja. Tako je nastavnom predmetu Glazbena kultura dodijeljeno pola sata tjedno ili po jedan sat svaki drugi tjedan (Škojo, 2015a, 49-50) ili jedan sat tjedno tijekom jednog polugodišta, što je ovisilo o organizaciji nastave, odnosno raspodjeli zaduženja nastavnika. Čak i s dvostruko manjom satnicom nastava Glazbene kulture bila je i dalje u kontekstu dijakronijskog modela, odnosno kronološkog pregleda povijesti glazbe koji je pratio razvoj glazbene umjetnosti od njezinih prvih početaka do kraja 18. stoljeća za prvu godinu učenja te obilježja glazbe romantizma i suvremene glazbe 20. stoljeća za drugu godinu učenja. Otežavajuće okolnosti bile su nerealni omjer satnice i nastavnog sadržaja, jedna zaključna ocjena iz dvaju različitih umjetničkih područja te činjenica da je uglavnom isti nastavnik poučavao obje umjetnosti čija kompetentnost za oba područja često puta nije bila nivelirana. Unatoč tome, postoje primjeri kvalitetne prakse u kojoj nastavnici neglazbene struke za poučavanje Glazbene umjetnosti uz udžbenike Stoljeća govore glazbom 1 (Čelar i Njirić, 1987) i Stoljeća govore glazbom 2 (Kos, 1987) koriste raznovrsne metode rada te nastavna sredstva i pomagala kao što su panoi sa slikama umjetnika, fotografijama i crtežima, članci i kritike iz novina, radne bilježnice, el. gramofon, gramofonske ploče, kasetofon i kasete, kompleti dijapozitiva i dijafilmova te prilozi iz poezije i likovne umjetnosti (Izvještaj o pregledu pedagoško-instruktivnog rada odgojno-obrazovnih zadataka u nastavi Glazbene kulture, CUO »Vilim Galjer« Đurđevac, 1986).

Nešto drugačiji nastavni plan i program nastave glazbe s mogućom većom satnicom imalo je usmjereno obrazovanje u odgojno-obrazovnoj i kulturološkoj struci (Okvirni obrazovni programi sadržaja struke u prvoj $i$ drugoj godini usmjerenog obrazovanja, 1984) te kulturno-umjetničkoj struci (Okvirni obrazovni programi usmjerenog obrazovanja, 1988). Tako u nastavnom planu odgojno-obrazovne struke odgajatelja 
djece predškolskog uzrasta i nastavnika razredne nastave, uz obavezno učenje Umjetnosti (Likovne i glazbene kulture) za prve dvije godine sa satnicom od jednog sata tjedno, bila je ponuđena i izborna nastava Glazbeni odgoj sa sviranjem s predviđena dodatna dva sata tjedno tijekom prve dvije godine i mogućnošću daljnjeg učenja kroz sve četiri godine srednjeg obrazovanja. Osnovna koncepcija nastavnog programa Glazbenog odgoja obuhvaćala je rad na glazbenoj pismenosti, odgoj sluha i ritma, oblikovanje glasa, glazbeno stvaralaštvo, upoznavanje većeg broja narodnih, dječjih i umjetničkih brojalica, pjesama i igara, sviranje na ritmičkom i melodijskim udaraljkama te poznavanje skladbi prikladnih za slušanje s djecom. Literatura za nastavu bila je Teorija glazbe (Prek, S. i Završki, J.), Na usnama pjesma (Manasteriotti, V.) i Male skladbe velikih majstora (Reich, T).

Kulturološka struka imala je dva područja rada: Kultura s informativnom i izdavačko-knjižarskom djelatnošću te Glazbena i plesna umjetnost. Oba područja imala su nastavni predmet Likovna i glazbena kultura s fondom od 34 sata za prve dvije godine učenja, s napomenom da se u prvome području rada moglo realizirati i proširenje fonda sati. To je značilo da bi se u prvoj godini učenja moglo obraditi i dio gradiva druge godine (do L. van Beethovena i romantizam), dok bi se u drugoj godini obrađivali jugoslavenski skladatelji. Velik značaj davao se slušnom upoznavanju što većeg broja glazbenih djela i to u omjeru dvije trećine vremena nastavnog sata (Okvirni obrazovni programi sadržaja struke u prvoj i drugoj godini usmjerenog obrazovanja, 1984, 16). Područje rada Glazbene i plesne umjetnosti bilo je namijenjeno učenicima koji su nakon osnovne glazbene, odnosno plesne škole, ili dvogodišnjeg pripremnog programa nastavili svoje obrazovanje u srednjoj glazbenoj ili plesnoj školi uz koju su upisali program kulturološke (ili odgojno-obrazovne) struke. Učenici glazbenih programa nisu imali obvezu pohađati nastavu Glazbene kulture, već su sadržaje predmeta savladavali u okviru predmeta struke u glazbenoj školi.

Okvirni obrazovni program usmjerenog obrazovanja (1988) donio je nastavni plan i program kulturno-umjetničke struke za područje rada Kultura po kojem se obrazovao profil suradnika u kulturno-znanstvenim ustanovama (arhivi, muzeji, galerije, biblioteke, znanstveno-istraživačke institucije...) te za područje rada Kultura s informativnom $i$ izdavačko-knjižarskom djelatnošću po kojem se obrazovao profil suradnika u INDOK (informacijsko-dokumentacijsko-komunikacijskoj) 
djelatnosti. Likovna i glazbena kultura i dalje su pripadale jednom nastavnom predmetu, a satnica kroz prve dvije godine učenja bila je udvostručena na 68 sati godišnje. No postojala je mogućnost razdvajanja u zasebne predmete: Likovna kultura po 34 sata u prvoj i drugoj godini učenja, odnosno Glazbena kultura također po 34 sata u prvoj i drugoj godini. Nastavni program je odgovarao programu proširenog fonda sati iz područja rada Kultura s informativnom i izdavačko-knjižarskom djelatnošću.

U obrazovnom profilu suradnika u kulturno-znanstvenim ustanovama nastavni plan četvrte godine imao je 32 sata Glazbene kulture, a program je obuhvaćao različite vremenske i stilske epohe te stvaralaštvo jugoslavenskih skladatelja. Sada su po prvi puta bez kronološkog pristupa u obradi povijesti glazbe, učenici i nastavnici imali slobodu odabira sadržaja rada i izbora tematskih cjelina koje su prilagođavali trenutnim zbivanjima u glazbenom životu: programu radija, televizije, koncerata, scenskih glazbenih izvedbi, filmova ili manifestacija (Okvirni obrazovni programi usmjerenog obrazovanja, 1988, 38-39). U okviru ovog predmeta također su se obrađivali i sadržaji Glazbene kulture iz programa zajedničke osnove u trećoj godini, tako da je nastava glazbe u ovome profilu bila prisutna kroz gotovo sve četiri godine strukovnog obrazovanja. Nastavu glazbe mogao je izvoditi profesor povijesti glazbe ili diplomirani muzikolog.

Sličnu koncepciju imao je i profil suradnika u INDOK djelatnosti, s time da je ovaj program nakon prve dvije godine učenja Glazbene kulture bio pojačan mogućom izbornom nastavom Glazbene kulture u trećem razredu s 34 nastavna sata i redovnom nastavom u četvrtom razredu s 32 nastavna sata. U nastavi se koristilo prijašnje stečeno znanje o povijesnom razvoju glazbe te aktivno i analitičko slušanje za daljnje upoznavanje zanimljivih glazbenih ostvarenja i aktualnih zbivanja u glazbenom životu. Korištena literatura bila je Stoljeća govore glazbom 1 (A. Čelar i N. Njirić), Stoljeća govore glazbom 2 (K. Kos), Vječni Orfej (J. Andreis), Stoljeća hrvatske glazbe (L. Županović) i 111 opera (N. Turkalj). Nastavu je mogao izvoditi profesor glazbene kulture, profesor teoretskih muzičkih predmeta ili diplomirani muzikolog, pod uvjetom da je završio pedagošku skupinu predmeta. Opremljenost (specijalizirane) učionice zahtijevala je školsku ploču s muzičkim crtovljem, klavir (pianino), kazetofon, gramofon, odgovarajuću fonoteku, video-rekorder i televizor u boji.

Odgojno-obrazovni zadatci nastave Glazbene kulture za treću i četvrtu godinu kulturno-umjetničke struke bili su razvijanje glazbenog 
senzibiliteta kod učenika; upoznavanje učenika s bitnim karakteristikama glazbeno-stilskih razdoblja; razvijanje kulture slušanja i aktivan odnos prema djelu; razvijanje kriterija za vrednovanje glazbenog djela i potrebe za aktivnim praćenjem glazbenog života; obogaćivanje glazbenog ukusa učenika; razvijanje poštovanja prema kulturnoj tradiciji i odgajanje društveno aktivnih i svestrano obrazovanih kulturnih ličnosti. Programski sadržaji bili su stavljeni na izbor nastavniku, a temeljili su se na teorijskome pristupu, aktivnom slušanju, odlascima na glazbena događanja, posjetima glazbenim ustanovama i komunikaciji s glazbenim stručnjacima. Neke od nastavnih jedinica bile su: koncert, koncertna dvorana, koncertni umjetnik, koncertna agencija, muzičko školstvo, muzikologija, instrumenti simfonijskog orkestra, uređaji za reprodukciju glazbe, narodna umjetnost, glazba jugoslavenskih naroda, klasici i avangarda 20. stoljeća, romantizam 19. stoljeća, klasika u muzici, polifonija renesanse i baroka, uključivanje nastavnika i učenika u aktualne glazbene događaje, razvijanje odnosa prema bezvrijednom i kiču u glazbi te usporedba različitih stilskih komponenata i različitih izvedbi i aranžmana. Ovakva koncepcija nastavnog programa koju su nastavnici mogli samostalno osmisliti prema zadanom okviru, ali i prema interesima učenika te glazbenim aktualnostima, primjer je otvorenog modela nastave glazbe. Takav model ipak nije dugoročno zaživio u praksi.

Slijedom brojnih promjena nakon raspada SFRJ, 1991. godine Ministarstvo prosvjete i kulture Republike Hrvatske usvojilo je prijed$\log$ Zavoda za školstvo Promjene sustava srednjeg obrazovanja kojim su ponovno uvedene tri vrste srednjih škola: gimnazije, umjetničke i stručne srednje škole. Promjene su 1992. potvrđene Zakonom o srednjem školstvu (Batinić, 2003, 56), a nastava glazbe 1994. godine postaje samostalni nastavni predmet koji je pod nazivom Glazbena umjetnost prisutan sve do danas kao dio umjetničkog područja kurikuluma srednjoškolskog općeg obrazovanja učenika.

\section{Opće značajke današnje nastave Glazbene umjetnosti}

Prema službenom Nastavnom programu za gimnazije (1994., 2015.), nastava Glazbene umjetnosti izvodi se tijekom svih četiriju razreda u općim, jezičnim i klasičnim gimnazijama sa satnicom od jedan sat tjedno. U prirodoslovno-matematičkim gimnazijama izvodi 
se tijekom prvih dvaju razreda sa satnicom od jedan sat tjedno, dok se u prirodoslovnim gimnazijama izvodi samo u četvrtom razredu i to sa satnicom od dva sata tjedno. U općim gimnazijama moguća je izborna nastava Glazbene umjetnosti i to od drugog do četvrtog razreda gimnazije sa satnicom do dva sata nastave tjedno. Prisutnost aktivnog muziciranja u hrvatskim općeobrazovnim srednjim školama ostvariva je jedino kroz izvannastavne glazbene aktivnosti (zborsko pjevanje, razne vrste komornih ansambala, band sastavi popularne glazbe, folklorne i plesne skupine, sviranje različitih instrumenata...), raznovrsne samostalne ili interdisciplinarne projekte te u izbornoj, odnosno dodatnoj ili fakultativnoj nastavi Glazbene umjetnosti čija se koncepcija temelji na proširivanju glazbenog znanja, aktivnom muziciranju (pjevanju, sviranju i plesu), kreativnom izražavanju te stvaralačkom radu. Ovu mogućnost nemaju sve škole jer ovisi o satnici, kompetencijama i ambicijama nastavnika Glazbene umjetnosti, afinitetima učenika te materijalnim uvjetima i politici škole.

Cilj nastavnog predmeta Glazbena umjetnost sveobuhvatan je odgoj mladeži u kulturi, odgoj poznavatelja temeljnih značajki glazbe i po mogućnosti aktivnoga sudionika u glazbenom životu svoje životne sredine (Nastavni program za gimnazije, 1994, 77). Rojko (2005, 300 ) ističe da je cilj nastave Glazbene umjetnosti pružiti učenicima što je moguće šire obrazovanje u okviru sveobuhvatnog humanističkog, društvenog, prirodoslovno-matematičkog, kulturnog i umjetničkog područja koje omogućuje gimnazijski program. Vidulin-Orbanić i Duraković $(2012,14)$ opisuju da je cilj nastave Glazbene umjetnosti razumijevanje glazbenih djela svjetske i nacionalne kulturne baštine koje je usmjereno prema poticanju i razvijanju zanimanja, navike i potrebe bavljenja glazbom, podizanju razine glazbene i opće kulture te poticanju estetskoga razvoja učenika. Dobrota $(2012,10)$ ističe da je cilj nastave glazbe, a tako i Glazbene umjetnosti, estetsko odgajanje učenika, odnosno razvijanje sposobnosti opažanja, doživljavanja, vrednovanja i ostvarivanja lijepoga kako bi se razvijao glazbeni ukus učenika i kako bi se stvorili kritički slušatelji koji će u glazbi različitih stilova znati razlikovati kvalitetna od nekvalitetnih glazbenih ostvarenja. Slično su definirale i Škojo $(2015,51)$ te Šimunović i Svalina $(2015,46,65)$ koje naglašavaju (u: Rojko, 1996, 52) da je cilj nastave Glazbene umjetnosti odgoj kompetentnoga i kritičnoga slušatelja i po- 
znavatelja glazbe, odnosno razvijanje glazbenog ukusa i odgoj buduće glazbene publike.

Zadatci predmeta Glazbena umjetnost odnose se na nastavak osnovnoškolskog obrazovanja i to kroz upoznavanje izražajnih sredstava glazbe i njezinih sastavnica, slušnu i teorijsku nadopunu poznavanja izvođačkih sastava, upoznavanje glazbenih oblika i vrsta glazbenih djela, razlikovanje stilskih značajki različitih glazbenih razdoblja, upoznavanje umjetničkih glazbenih djela svjetske, hrvatske i suvremene literature i podataka o njihovim stvarateljima, razvijanje i stjecanje znanja i novih spoznaja o glazbenoj umjetnosti, osposobljavanje učenika da na temelju stečenog znanja mogu sami približno procijeniti umjetničku razinu djela koja slušaju te poticanje na praćenje glazbenoga (i cjelokupnoga umjetničkoga) života uže i šire životne sredine (Nastavni program za gimnazije, 1994, 78).

Rojko $(2005,300)$ navedene zadatke pojednostavljuje i klasificira te izdvaja one koje učenici trebaju ostvariti (Tablica 1).

Tablica 1. Zadatci nastave glazbe u gimnaziji (Rojko, 2005, 300)

\begin{tabular}{|c|l|}
\hline \multicolumn{1}{|c|}{ Zadatci } & \multicolumn{1}{c|}{ Realizacija zadataka } \\
\hline Materijalni: & $\begin{array}{l}\text { 1. Upoznati i naučiti pojavne oblike glazbe (glazbeni oblici i } \\
\text { glazbene vrste); } \\
\text { glazbennati, naučiti, zapamtiti određen (što veći) broj }\end{array}$ \\
$\begin{array}{l}\text { 3. Upoznati, naučiti neke osnovne i važne podatke iz glazbene } \\
\text { povijesti; }\end{array}$ \\
\hline Funkcionalni: & 4. Steći glazbeni ukus. \\
\hline
\end{tabular}

Iako Rojko izostavlja odgojne zadatke, Dobrota $(2012,10)$ ističe da su oni ionako latentno prisutni u svim aktivnostima nastave glazbe zbog kontinuirane procjene glazbeno-estetskih vrijednosti i u materijalnim (znanja, činjenice i generalizacije) i u funkcionalnim (razvoj senzornih, perceptivnih, izražajnih i kreativnih sposobnosti) zadatcima.

Od uvođenja Nacionalnog okvirnog kurikuluma za predškolski odgoj i obrazovanje te opće obvezno i srednjoškolsko obrazovanje (NOK, 2011), velika se pozornost pridaje ostvarenju učeničkih postignuća, odnosno postizanju određenih obrazovnih ishoda koji su usmjereni na razvijanje učeničkih kompetencija, što obuhvaća kombinaciju zna- 
nja, umijeća, uvjerenja, motivacije i osobne karakteristike potrebnih da pojedinac aktivno, stručno i efikasno djeluje u određenoj situaciji (Mijatović, 2000, Staničić, 2001, u: Vidulin-Orbanić i Duraković, 2012, 19). Ovaj kurikulumski pristup teži prijelazu s tradicionalnog odgojno-obrazovnog sustava usmjerenog na prenošenje činjeničnog znanja na razvoj kompetencija učenika i osnaživanje odgojne dimenzije u nastavnom procesu. To predstavlja zaokret u metodama, načinima i oblicima rada od kojih se preporuča problemsko učenje, učenje u parovima i skupinama, istraživačka, iskustvena i projektna nastava te upotreba multimedijskog $\mathrm{i}$ interdisciplinarnog pristupa. $\mathrm{U}$ nastavi Glazbene umjetnosti vrednovanje obrazovnih ishoda ostvaruje se kroz usmeni ili pismeni oblik provjere usvojenosti znanja, poznavanje glazbene literature te kroz samostalni rad, aktivnost i zalaganje. Nastavu mogu izvoditi dipl. muzikolog, prof. glazbene kulture, prof. teorijskih glazbenih predmeta, prof. muzikologije, magistar muzikologije, magistar glazbene pedagogije i magistar muzike, pod uvjetom da su završili studij muzikologije, studij glazbene pedagogije ili studij glazbene kulture.

Uvođenjem Državne mature u Hrvatskoj 2010. godine kao izborni predmet moguće je odabrati i Glazbenu umjetnost. Ispit se sastoji od dviju cjelina gdje se u prvoj ispituju opća teorijska znanja, dok se u drugoj cjelini ispituje sposobnost analize dvaju glazbenih primjera pojedinačno i usporedno. Područja ispitivanja, posebni ciljevi, potrebna literatura, popis glazbenih primjera, njihov zvučni zapis u mp3 formatu te struktura ispita i izgled zadataka detaljno se navode i opisuju u Ispitnom katalogu za državnu maturu koji je u dostupan svake nove školske godine u revidiranom izdanju na mrežnoj stranici Nacionalnog centra za vanjsko vrednovanje obrazovanja. Od školske godine 2016./17. Muzička akademija Sveučilišta u Zagrebu uvela je kao obavezan preduvjet za upis na studijske programe Teorija glazbe, Muzikologija (jednopredmetno i dvopredmetno) i Glazbena pedagogija (jednopredmetno i dvopredmetno) Državnu maturu iz predmeta Glazbena umjetnost. U usporedbi sa školskom godinom 2015./16., kada je u Hrvatskoj na Državnu maturu iz Glazbene umjetnosti pristupilo svega 16 učenika, u školskoj godini 2016./17. Državnu maturu iz Glazbene umjetnosti položilo je ukupno 94 učenika, s prosječnom ocjenom vrlo dobar. Vidljivo je da je ova strategija dovela do znatnog povećanja kandidata, čime se jamči održivost ovoga predmeta na Državnoj maturi. 


\section{Modeli poučavanja nastave glazbe u općeobrazovnim srednjim školama}

Od donošenja službenog plana i programa nastave glazbe u gimnaziji u školskoj godini 1954./55. pa sve do danas, nastava Glazbene umjetnosti izvodi se prema dijakronijskom modelu koji u kronološkom slijedu označava prikaz historijskog razvitka glazbene umjetnosti. Temeljem aktualnog nastavnog programa Glazbene umjetnosti koji je definiran 1994. godine (Nastavni program za gimnazije, 1994; 1999; 2015, 77-89), programska je građa usmjerena na teorijsko i slušno upoznavanje sastavnica glazbenog djela, glazbenih oblika i vrsta umjetničke glazbe. Te se sastavnice obrađuju u kontekstu kronološki poredanih stilskih razdoblja od starog vijeka do 20. stoljeća. Poseban značaj pridaje se biografijama skladatelja, dok se predviđene skladbe za slušanje mogu upoznati informativno ili formalnom analizom u kojoj se određuju sastavnice glazbenog djela. Pregled stilskih razdoblja ne opisuje se samo u glazbenom nego i u društveno-povijesnom kontekstu s brojnim korelacijama iz područja likovne umjetnosti, povijesti, geografije, književnosti, filozofije, arhitekture, matematike i fizike, a sve u cilju, kako ističu Vidulin-Orbanić i Duraković $(2012,10)$, dobivanja cjelovite slike razvoja glazbe u povijesti društva.

Nastavni program Glazbene umjetnosti za četverogodišnje gimnazije u početku se izvodio uz primjenu udžbenika Stoljeća govore glazbom 1 (Čelar, A. i Njirić, N.) i Stoljeća govore glazbom 2 (Kos, K.) izdavačke kuće Školska knjiga, dok posljednjih sedamnaest godina nastavu Glazbene umjetnosti prate dvije vrste udžbenika s tri zvučna CD-a za svaki razred:

- Glazbeni susreti 1., 2., 3., i 4. vrste (Perak Lovričević, N. i Ščedrov, Lj.) izdavačke kuće Profil Klett;

- Glazbena umjetnost 1. i 2. (Medenica, N.) i Glazbena umjetnost 3. i 4. (Medenica, N. i Palić Jelavić, R.) izdavačke kuće Školska knjiga.

Iako obje vrste udžbenika imaju sličan raspored muzikoloških sadržaja, slijedi prikaz koncepcije dijakronijskog modela prema Izvedbenom nastavnom programu Glazbene umjetnosti za prvi, drugi, treći i četvrti razred četverogodišnje gimnazije izdavačke kuće Profil Klett (Tablica 2-5). 
Tablica 2. Izvedbeni nastavni program Glazbene umjetnosti za prvi razred gimnazije

\begin{tabular}{|l|l|}
\hline \multicolumn{1}{|c|}{ Nastavna cjelina } & \multicolumn{1}{c|}{ Nastavne jedinice } \\
\hline Sastavnice glazbenog djela & $\begin{array}{l}\text { Zvuk, šum i ton; Izvođači glazbenog djela: glasovi i glaz- } \\
\text { bala; Izvođački sastavi; Tempo, metar i ritam; Melodija } \\
\text { i harmonija; Glazbeni slog; Glazbeni oblik; Tonska gra- } \\
\text { đa, ljestvice }\end{array}$ \\
\hline $\begin{array}{l}\text { Razvoj glazbe kroz stilska } \\
\text { razdoblja }\end{array}$ & Pregled razvoja glazbe \\
\hline Glazba u starom vijeku & Glazba starih Grka \\
\hline $\begin{array}{l}\text { Jednoglasna glazba u } \\
\text { srednjem vijeku }\end{array}$ & $\begin{array}{l}\text { Crkvena glazba-gregorijanski koral; Glagoljaško pjeva- } \\
\text { nje; Svjetovna jednoglasna glazba }\end{array}$ \\
\hline $\begin{array}{l}\text { Srednjovjekovna } \\
\text { višeglasna glazba }\end{array}$ & $\begin{array}{l}\text { Rano polifono višeglasje; Srednjovjekovni višeglasni } \\
\text { oblici; Srednjovjekovna instrumentalna glazba }\end{array}$ \\
\hline Renesansa - uvođenje stila & Uvod u renesansu; Značajke renesansne glazbe \\
\hline Crkvena glazba renesanse & Misa; Motet \\
\hline $\begin{array}{l}\text { Svjetovna glazba } \\
\text { renesanse }\end{array}$ & $\begin{array}{l}\text { Višeglasne popijevke (frottola, villanella); Madrigal; In- } \\
\text { strumentalna glazba }\end{array}$ \\
\hline
\end{tabular}

Tablica 3. Izvedbeni nastavni program Glazbene umjetnosti za drugi razred gimnazije

\begin{tabular}{|l|l|}
\hline \multicolumn{1}{|c|}{ Nastavna cjelina } & \multicolumn{1}{c|}{ Nastavne jedinice } \\
\hline Barok - uvođenje stila & Uvod u barok; Značajke barokne glazbe \\
\hline Instrumentalne vrste baroka & $\begin{array}{l}\text { Concerto grosso; Solistički koncert; Barokna suita; } \\
\text { Barokna sonata }\end{array}$ \\
\hline $\begin{array}{l}\text { Vokalno-instrumentalne vrste } \\
\text { baroka }\end{array}$ & Opera, Kantata i oratorij; Pasija; Barokni motet \\
\hline Pretklasicizam i klasicizam & $\begin{array}{l}\text { Uvod u pretklasicizam i klasicizam (galantni i osjećaj- } \\
\text { ni stil); Stilske glazbene značajke; Couperinov rondo } \\
\text { i Scarlattijeva sonata; Pretklasicistička simfonija }\end{array}$ \\
\hline $\begin{array}{l}\text { Klasični instrumentalni } \\
\text { ciklusi bečke klasike }\end{array}$ & $\begin{array}{l}\text { Klasični instrumentalni ciklusi (Sonata, simfonija, } \\
\text { koncert, gudački kvartet); Simfonija - sonatni oblik; } \\
\text { Sonata - klasični rondo s epizodama; Klasični rondo } \\
\text { s dvije i tri teme; Komorna glazba klasicizma - tema } \\
\text { s varijacijama; Komorna glazba klasicizma - složeni } \\
\text { trodijelni oblik; Koncert }\end{array}$ \\
\hline $\begin{array}{l}\text { Vokalno-instrumentalne vrste } \\
\text { klasicizma }\end{array}$ & $\begin{array}{l}\text { Gluckova operna reforma (Opera seria); Opera buffa; } \\
\text { Mozartove opere; Oratorij i misa }\end{array}$ \\
\hline
\end{tabular}


Tablica 4. Izvedbeni nastavni program Glazbene umjetnosti za treći razred gimnazije

\begin{tabular}{|l|l|}
\hline \multicolumn{1}{|c|}{ Nastavna cjelina } & \multicolumn{1}{c|}{ Nastavne jedinice } \\
\hline $\begin{array}{l}\text { Na razmeđu klasicizma } \\
\text { i romantizma }\end{array}$ & $\begin{array}{l}\text { Ludwig van Beethoven - posljednji bečki klasičar i prvi } \\
\text { romantičar }\end{array}$ \\
\hline $\begin{array}{l}\text { Romantizam - uvođenje } \\
\text { stila }\end{array}$ & Uvod u romantizam; Značajke glazbenog romantizma \\
\hline Romantizam & $\begin{array}{l}\text { Nacionalni stil; Nacionalni stil - hrvatska glazba u 19. st.; } \\
\text { Programna glazba - M. P. Musorgski: Slike s izložbe; Pro- } \\
\text { gramna glazba }\end{array}$ \\
\hline $\begin{array}{l}\text { Glazbene vrste } \\
\text { romantizma }\end{array}$ & $\begin{array}{l}\text { Solo pjesma; Glasovirska minijatura - F. Chopin i R. Schu- } \\
\text { mann; Simfonijska pjesma - B. Smetana: Vltava; Simfonij- } \\
\text { ska pjesma - R. Strauss: Vragolije Tilla Eulenspiegela; Ro- } \\
\text { mantička simfonija; Romantička suita; Koncert u 19. st. }\end{array}$ \\
\hline $\begin{array}{l}\text { Vokalno-instrumentalne } \\
\text { vrste romantizma }\end{array}$ & $\begin{array}{l}\text { Ranoromantička talijanska opera; Nacionalna opera; Hr- } \\
\text { vatska opera u 19. stoljeću; Opere G. Verdija; Wagnerova } \\
\text { operna reforma; Operni realizam i verizam }\end{array}$ \\
\hline Impresionizam & Impresionizam - značajke glazbenog stila \\
\hline
\end{tabular}

Tablica 5. Izvedbeni nastavni program Glazbene umjetnosti za četvrti razred gimnazije

\begin{tabular}{|l|l|}
\hline \multicolumn{1}{|c|}{ Nastavna cjelina } & \multicolumn{1}{c|}{ Nastavne jedinice } \\
\hline $\begin{array}{l}\text { Glazbena umjetnost prve } \\
\text { polovice 20. stoljeća }\end{array}$ & Uvod u glazbu 20. stoljeća; Značajke glazbenog izraza \\
\hline $\begin{array}{l}\text { Glazbeni } \\
\text { ekspresionizam }\end{array}$ & $\begin{array}{l}\text { Glazbeni ekspresionizam - slobodni atonalitet; Organizi- } \\
\text { rani atonalitet (dvanaesttonska tehnika skladanja); Druga } \\
\text { bečka škola; Opera u 1. polovini 20. stoljeća (A. Berg: } \\
\text { Wozzeck) }\end{array}$ \\
\hline $\begin{array}{l}\text { Neoromantizam i } \\
\text { nacionalni stilovi } \\
\text { 20. stoljeća }\end{array}$ & $\begin{array}{l}\text { Nacionalni stil u 20. st. - Ruska nacionalna škola; Nacio- } \\
\text { nalni stil u 20. st. - balet u 20. st.; Folklor u suvremenom } \\
\text { glazbenom ruhu (Béla Bartók); Hrvatski skladatelji u pr- } \\
\text { voj polovini 20. stoljeća J. S. Slavenski i J. Gotovac, D. } \\
\text { Pejačević i B. Bersa }\end{array}$ \\
\hline Neoklasicizam & Simfonija; Koncert i sonata \\
\hline Neobarok & Fuga i passacaglia; Kantata \\
\hline $\begin{array}{l}\text { Glazbena umjetnost druge } \\
\text { polovice 20. stoljeća }\end{array}$ & $\begin{array}{l}\text { Serijalna tehnika skladanja i aleatorika ili nedeterminaci- } \\
\text { ja; Oslobađanje zvuka; Konkretna i elektronička glazba }\end{array}$ \\
\hline Jazz glazba & Značajke jazza; Stilovi jazza; Musical \\
\hline $\begin{array}{l}\text { Zabavna glazba u drugoj } \\
\text { polovici 20. stoljeća }\end{array}$ & $\begin{array}{l}\text { Značajke rock-glazbe; Stilovi rock-glazbe: rock šezdesetih, } \\
\text { sedamdesetih, osamdesetih i devedesetih; World music }\end{array}$ \\
\hline
\end{tabular}


Iz prikazanog nastavnog programa može se zaključiti da je svaka godina učenja nastave glazbe hermetički zatvorena cjelina koja ne pruža mogućnost otvorenijeg i suvremenijeg pristupa poučavanju glazbe. Dijakronijski model stoga, prema Rojku $(2001,6)$, može imati negativne motivacijske učinke na učenike. Razlog tome je historijski pristup obradi sadržaja, ali i opsežnost teorijskih podataka o nastavnim temama zbog čega se ne stiže aktivno slušati i kvalitetno analizirati predviđene skladbe. Također, nije predviđena obrada suvremenijih tema koje su u skladu s interesima učenika, analitički pristup utjecajnih faktora na glazbene preferencije slušatelja te razvoj pozitivnog ili negativnog kritičkog mišljenja prema glazbi u nastavi, odnosno u slobodnom vremenu učenika. U četverogodišnjem nastavnom programu pojedine glazbene vrste i oblici obrađuju se i po nekoliko puta (opera, kantata, simfonija, koncert, suita, sonata...) ovisno o glazbenom stilskom razdoblju, što posljedično daje istovrsnost i predvidivost koncepcije nastavnog predmeta. Nadalje, zbog heterogenog sastava učenika gimnazije upitna je i funkcionalnost brojnih notnih zapisa u udžbenicima Glazbene umjetnosti jer nemaju svi glazbeno obrazovanje za praćenje nota s razumijevanjem. K tome, u praksi se dugi niz godina daje velik značaj biografijama skladatelja koje učenici često obrađuju sami, nakon čega se glazba sluša informativno. Činjenicom da je teorijsko-muzikološka interpretacija nastavnog sadržaja još uvijek u prvome planu te ispred samoga učenika, pa čak i glazbe, uskraćuje se mogućnost otvorenog modela poučavanja te sudjelovanja učenika u sukonstrukciji kurikuluma, čemu teži suvremena pedagogija.

Analiza udžbenika Glazbeni susreti 1., 2., 3. i 4. vrste koji prate nastavni program dijakronijskog modela pokazuje da knjige sadrže više slojeva teksta: obvezne podatke koji pripadaju gradivu (karakteristike glazbenih stilova, glazbeni oblici i vrste), neobvezne tekstove koji služe poticanju interesa i radoznalosti učenika (životopisi skladatelja, usporedbe s istodobnim događajima i stilovima u drugim umjetnostima, povezivanje sa suvremenim životom i sl.) te poglavlja koja nisu obuhvaćena obveznim programom, a nastavnik ih može povezivati s obveznim gradivom (npr. tradicijska glazba, jazz i rock). Može se zaključiti da je sadržaj u udžbenicima prilično detaljno razrađen, a upotpunjuju ga i brojne slike, ilustracije, notni primjeri te zadatci za slušanje glazbe i ponavljanje gradiva. Takav udžbenik, u odnosu na satnicu od jednog sata tjedno i cilj samoga predmeta, osim što sveobuhvatno obrazuje, također učenika usmjerava prema učenju povijesti glazbe. To potvrđuje i Ščedrov koja ističe da se ovi udžbenici zbog širine obrađenog glazbenog gradiva mogu koristiti i u srednjoj glazbenoj školi za nastavu 
Povijesti glazbe (Ščedrov, 2000, 16). Nastavnik Glazbene umjetnosti stoga treba biti vrlo razborit u odabiru ponuđenog nastavnog sadržaja koji se nalazi u udžbenicima kako se ne bi otišlo u veliku sadržajnu širinu jer ne postoje priručnici za nastavnike osim priručnika Glazbeni susreti 2. vrste za drugi razred gimnazije (Krgović, 2008) i nedavno objavljenog e-nastavnog priručnika uz udžbenik Glazbeni susreti 3. vrste (Krgović, 2016) koji je dostupan na mrežnoj stranici https://www.profil-klett.hr/metodicki-kutak. Autorica obaju priručnika detaljno je razradila svaku nastavnu jedinicu prema didaktičko-metodičkim kriterijima, zorno prikazujući artikulaciju svakog sata koji se temelji na slušanju i analizi umjetničkih glazbenih djela i to isključivo temeljem metode razgovora s učenicima. Navedeni priručnici značajno su doprinijeli nastavi Glazbene umjetnosti u Hrvatskoj, a nastavnicima su dane konkretne upute za kvalitetno poučavanje nastave glazbe prema dijakronijskom modelu.

Izbor i tijek obrade sadržaja dvogodišnjeg nastavnog programa Glazbene umjetnosti za prirodoslovnu i prirodoslovno-matematičku gimnaziju ostaje nepromijenjen, s jedinom razlikom što je u dvogodišnjem programu cjelokupno povijesno gradivo sažeto na dvostruko manje nastavno vrijeme, tj. sadržaj prvog i drugog razreda postaje sadržaj prvoga, a sadržaj trećeg i četvrtog sada je sadržaj drugog razreda. Nastavni program prati udžbenik Glazbeni kontakti 1. i 2. (Perak Lovričević, N. i Ščedrov, Lj.) izdavačke kuće Profil Klett s četiri nosača zvuka za svaki razred. Isti udžbenici koriste se i u nastavi Glazbene umjetnosti kod pojedinih strukovnih usmjerenja, kao na primjer u srednjoj školi primijenjenih umjetnosti i dizajna tijekom dvogodišnjeg programa Glazbene umjetnosti (grafički dizajner, tekstilni dizajner, kiparski dizajner i slikarski dizajner) ili tehničkoj gimnaziji u trećem i četvrtom razredu sa satnicom od jednog sata tjedno.

Nasuprot dijakronijskom modelu, u nastavi Glazbene umjetnosti obrada sadržaja moguća je i prema sinkronijskom modelu čiji je utemeljitelj Pavel Rojko. Model je osmišljen 2001. godine nakon čega je autor objavio knjigu Metodika glazbene nastave - praksa II. dio: Slušanje glazbe (Rojko, 2005) u kojoj detaljno opisuje sinkronijski pristup poučavanju nastave glazbe. Knjiga je oblikovana kao priručnik za nastavnike glazbe u osnovnim i srednjim općeobrazovnim školama te za potrebe nastave Povijesti glazbe u srednjoj glazbenoj školi. Sastavni je dio obvezne literature u poučavanju pedagoško-metodičkih predmeta na odsjecima za glazbenu pedagogiju u Hrvatskoj, no nakon studija glazbe vrlo mali broj nastavnika odlučuje se na ovakav način obrade glazbenih sadržaja. Razlog tome je što ne postoji službeni prijedlog četverogodišnjeg nastavnog 
programa sinkronijskog modela, već bi svaki nastavnik trebao osmisliti vlastiti nastavni program prema zadanom okviru. Škojo $(2013,305)$ ističe da pripremanje za nastavu prema sinkronijskom modelu jest angažiranije, temeljitije i zahtijeva dodatni trud, ali sukladno uloženom trudu, realizacija nastave je kreativnija, inventivnija i bolja. Ovakav pristup nastavi temelji se na fleksibilnoj metodologiji izrade i odabira sadržaja. Svaka nastavna jedinica ostvaruje se u trenutku kada se steknu svi uvjeti da poučavanje ostvari najbolje rezultate, a tijekom realizacije nastavnog programa moguće su korekcije (Škojo, 2016, u: Previšić, 2007).

Sinkronijski model u nastavi glazbe temelji se na principu višekratnog slušanja i formalne glazbene analize glazbenih oblika i vrsta obrađivanih kroz istovremenu usporednost glazbenih izričaja različitih stilskih razdoblja. Učenici tijekom jednog ili više sati tematske obrade trebaju upoznati i upamtiti određeni broj reprezentativnih umjetničkih glazbenih djela uz osnovne teorijsko-muzikološke značajke, čime se u prvi plan stavlja glazba, a ne kronološki slijed obrade povijesti glazbe s opsežnim biografijama skladatelja. Ovakvim modelom, osim što se postiže zanimljivost i raznolikost nastave, izbjegava se povijesno-teorijski pristup učenju glazbe te se mogu stvoriti preduvjeti za ostvarivanje zadataka glazbene nastave i kultiviranje glazbenog ukusa mladih (Škojo, 2010).

Istraživanje sinkronijskog modela u nastavi i njegovu usporedbu s tradicionalnim dijakronijskim modelom provela je Tihana Škojo tijekom dvije školske godine (2002./2003. i 2003./2004.) u III. gimnaziji u Osijeku. U istraživanju su sudjelovala dva prva razreda koja su praćena do kraja druge godine kad završava nastavnim programom predviđena Glazbena umjetnost u matematičkoj gimnaziji. Pri inicijalnom ispitivanju obje su grupe brojile po 30 ispitanika, dok se do završetka ispitivanja broj smanjio na 28 ispitanika u eksperimentalnoj i na 27 ispitanika u kontrolnoj grupi. Nastavni sadržaj sinkronijskog modela bio je u cijelosti zasnovan na slušanju glazbe. Aktivnim slušanjem i analizom najznačajnijih djela iz literature učenici su stjecali glazbena znanja i razvijali sposobnosti uočavanja. Uz aktivno slušanje, najvažniju ulogu imalo je višekratno slušanje kojim su učenici pamtili glazbena djela i stečena znanja nadograđivali u daljnjem nastavnom procesu (Škojo, 2010, 44). U uvodnom dijelu programa učenici su se upoznali s glazbenim pojavama i stvarali osnovna slušna i teorijska znanja na osnovu kojih su u daljnjem dijelu programa izgrađivali glazbene oblikovne strukture. Sinkronijsko načelo prilikom usvajanja svake nove glazbene pojavnosti primjenjivalo se tako da se je ista glazbena pojava upoznavala na što 
više različitih glazbenih primjera. U drugom dijelu programa učenici su upoznavali pojavne oblike glazbe, odnosno samu glazbu putem obrade glazbenih vrsta koje se prema preporuci autora modela mogu obrađivati proizvoljnim redoslijedom u skladu s dobi i afinitetima učenika. Upoznavanje skladatelja odvijalo se tako da su učenici tijekom slušnog upoznavanja i analize glazbenih oblikovnih struktura upoznavali najznačajnija i najvrjednija djela pojedinih skladatelja. U završnom dijelu programa učenici su dobili kronološki pregled povijesti glazbe klasificiranjem glazbenih djela koja su upoznali i izvođenjem konačnih zaključaka na temelju slušnog i teorijskog sadržaja. Samostalnim aktivnostima učenici su ponavljali upoznate glazbene primjere, dok su temeljem stečenih glazbenih znanja i iskustva sređivali kronološki pregled povijesti glazbe. Nastava glazbe temeljila se na radu bez udžbenika.

Slijedi prikaz nastavnog programa prema koncepciji sinkronijskog modela (Rojko, 2005, 309-310) koji je Škojo (2010) eksperimentalno provela u nastavi Glazbene umjetnosti tijekom školske godine 2002./2003. i 2003./2004. (Tablica 6)

Tablica 6. Izvedbeni dvogodišnji nastavni program Glazbene umjetnosti za matematičku gimnaziju prema sinkronijskom modelu (Škojo, 2010)

\begin{tabular}{|l|l|}
\hline \multicolumn{1}{|c|}{ Cjelina } & \multicolumn{1}{c|}{ Nastavne teme } \\
\hline $\begin{array}{l}\text { Usvajanje glazbene } \\
\text { terminologije }\end{array}$ & $\begin{array}{l}\text { melodija, ritam, harmonija, homofonija, polifonija, mjera, } \\
\text { tempo, dinamika, boja zvuka, motiv, fraza, motiv, složena } \\
\text { trodijelna pjesma, tema s varijacijama, rondo, sonatni oblik, } \\
\text { fuga, passacaglia. }\end{array}$ \\
\hline $\begin{array}{l}\text { Upoznavanje pojavnih } \\
\text { oblika glazbe }\end{array}$ & $\begin{array}{l}\text { sonata, koncert, gudački kvartet, komorne glazbene vrste, } \\
\text { simfonijski orkestar, simfonija, simfonijska pjesma, kla- } \\
\text { virska minijatura, solo pjesma, suita, fuga, misa, oratorij, } \\
\text { kantata, passacaglia, opera, opereta, musical, jazz i sklada- } \\
\text { telji (W. A. Mozart, L. van Beethoven, F. Chopin, C. De- } \\
\text { bussy...). }\end{array}$ \\
\hline Pregled povijesti glazbe & $\begin{array}{l}\text { kronološko sređivanje (u)poznatih glazbenih sadržaja u } \\
\text { vidu razgovora i slušanja glazbe. }\end{array}$ \\
\hline
\end{tabular}

Rezultati eksperimentalnog, preliminarnog istraživanja sinkronijskog modela u nastavi (Škojo, 2010), iako na malom uzorku učenika $(\mathrm{N}=30)$, pokazali su da su učenici koji su pohađali nastavu prema sinkronijskom modelu ostvarili značajno bolji uspjeh u slušnom prepoznavanju skladbi i određivanju skladatelja, formalnoj analizi glazbenih 
djela te u slušnom prepoznavanju glazbenog stila za razliku od učenika koji su pohađali nastavu prema dijakronijskom modelu. Također, rezultati završnog ispitivanja odnosa učenika prema predmetu pokazali su da su učenici podučavani sinkronijskim modelom razvili pozitivan odnos prema predmetu i spoznali značaj glazbene umjetnosti u njihovom kulturnom i društvenom životu. Nasuprot tome, učenici podučavani dijakronijskim modelom iskazali su nepromijenjena mišljenja o vrijednosti stečenih znanja. U testu poznavanja povijesti glazbe nije bilo statistički značajne razlike u rezultatima ispitanika. Razlike nije bilo ni u određenosti glazbenih preferencija, što je pokazalo da učenici obiju skupina nisu imali jasno usmjeren glazbeni ukus. Istraživanje je pokazalo i to da je provedba sinkronijskog modela u nastavi rezultirala motiviranijim učenicima koji su ostvarili pozitivan odnos prema glazbenoj umjetnosti, sa stavom da znaju primijeniti znanja i stečene vještine, kritički procjenjivati glazbena djela i prepoznavati glazbu niže vrijednosti. Zaključno, rezultati istraživanja sinkronijskog modela u nastavi ukazali su na potencijalno bolju učinkovitost poučavanja u nastavi Glazbene umjetnosti te su svakako poželjna daljnja longitudinalna istraživanja i to na većem uzorku sudionika. No, Dobrota i Kovačević (2007) ipak ističu zamjerku što sadržaj sinkronijskog modela predviđa glazbu koja pripada isključivo tradiciji zapadnog civilizacijskog kruga, dok se ostali, kulturno nepristupačni idiomi, iz njega isključuju, pa je takva koncepcija glazbenog obrazovanja suprotna interkulturalnoj koncepciji obrazovanja koja podrazumijeva uključivanje multikulturalnog sadržaja prezentiranog na autentičan način i zagovaranje jednakosti u procesima podučavanja i učenja za učenike iz različitih sredina (Dobrota i Kovačević, 2007, prema Banks i McGee, 1993).

Nastavni program sa sinkronijskim pristupom u nastavi izradilo je i Povjerenstvo za izradu općeobrazovnog dijela strukovnih kurikuluma u umjetničkom području prema Hrvatskom kvalifikacijskom okviru i to za smjerove Medijski tehničar i Web dizajner, kod kojih je Glazbena umjetnost predviđena u trećem i četvrtom razredu sa satnicom od jednog sata tjedno (Tablica 7). Nastavni program prihvatilo je Ministarstvo znanosti obrazovanja i sporta te se nakon eksperimentalne provedbe strukovnog kurikuluma u šk. god. 2013./14. redovno provodi u nastavi. U opisu predmeta stoji da predmet Glazbena umjetnost posredstvom slušanja, analize i upoznavanja glazbenih djela u kontekstu glazbeno-stilskih razdoblja omogućuje polazniku upoznavanje vokalnih, instrumentalnih i vokalno-instrumentalnih djela različitih vrsta, stilova, pravaca i žanrova. Cilj je nastavnog predmeta osposobiti polaznika za 
kritičko razmatranje glazbenih djela, što će utjecati i na njegovu estetsku prosudbu i sveukupni razvoj. S obzirom na to da za sinkronijski model poučavanja ne postoji službeni udžbenik za učenike kao ni priručnik za nastavnike osim Metodika glazbene nastave - praksa II. dio: Slušanje glazbe (Rojko, 2005), nastavnici svoje pripreme temelje na različitoj stručnoj literaturi i stručnim časopisima te ostalim publikacijama i internetskim stranicama. Učenici nastavu Glazbene umjetnosti mogu pratiti prema udžbeniku Glazbeni kontakti 1. i 2. (Perak Lovričević, N. i Ščedrov, Lj.) koji se nalazi u Katalogu obveznih udžbenika i pripadajućih dopunskih nastavnih sredstava za osnovnu školu, gimnazije i srednje strukovne škole Ministarstva znanosti i obrazovanja. Rezultati Evaluacije eksperimentalne provedbe i sadržaja strukovnih kurikuluma (2014, 44-45) pokazali su znatno više ocjene eksperimentalnog programa od dosadašnjeg, uz napomenu da, iako je nastava kreativnija i fleksibilnija, a program rasterećeniji, moderniji i prilagođen današnjem učeniku, materijalni uvjeti ipak ne prate zahtjeve kurikuluma jer je teško raditi bez temeljnog udžbenika zbog čega nastavnici trebaju pripremati dodatne materijale za učenike.

Tablica 7. Izvedbeni dvogodišnji nastavni program Glazbene umjetnosti za strukovnu školu, usmjerenje Medijski tehničar prema sinkronijskom modelu

(Gergorić i sur., 2012, u: Vidulin-Orbanić i Duraković 2012, 11-13)

\begin{tabular}{|c|c|c|c|}
\hline \multicolumn{2}{|c|}{$\begin{array}{l}\text { Nastavne cjeline i teme } \\
\text { u trećem razredu }\end{array}$} & \multicolumn{2}{|c|}{$\begin{array}{l}\text { Nastavne cjeline i teme } \\
\text { u četvrtom razredu }\end{array}$} \\
\hline Vokalna glazba & $\begin{array}{l}\text { Gregorijanski koral } \\
\text { Misa } \\
\text { Motet } \\
\text { Madrigal } \\
\text { Višeglasna popijevka }\end{array}$ & Vokalna glazba & $\begin{array}{l}\text { Zborska glazba } \\
\text { Klapska pjesma } \\
\text { Gospel } \\
\text { Narodna pjesma } \\
\text { Suvremeni vokalni izričaj }\end{array}$ \\
\hline $\begin{array}{l}\text { Vokalno- } \\
\text { instrumentalna } \\
\text { glazba }\end{array}$ & $\begin{array}{l}\text { Opera } \\
\text { Oratorij } \\
\text { Kantata }\end{array}$ & $\begin{array}{l}\text { Vokalno- } \\
\text { instrumentalna } \\
\text { glazba }\end{array}$ & $\begin{array}{l}\text { Solo pjesma } \\
\text { Opereta } \\
\text { Musical } \\
\text { Narodna glazba } \\
\text { Popularna glazba }\end{array}$ \\
\hline $\begin{array}{l}\text { Instrumentalna } \\
\text { glazba }\end{array}$ & $\begin{array}{l}\text { Suita } \\
\text { Sonata } \\
\text { Koncert } \\
\text { Gudački kvartet } \\
\text { Simfonija }\end{array}$ & $\begin{array}{l}\text { Instrumentalna } \\
\text { Glazba }\end{array}$ & $\begin{array}{l}\text { Klavirska minijatura } \\
\text { Balet } \\
\text { Društveni plesovi } \\
\text { Moderni plesovi }\end{array}$ \\
\hline
\end{tabular}


Obrazovni ishodi usmjereni su na teorijsko identificiranje značajki vokalnih, vokalno-instrumentalnih i instrumentalnih glazbenih vrsta u kontekstu glazbeno-stilskih razdoblja; slušno prepoznavanje i analiziranje značajki glazbenih vrsta u zvučnim primjerima; prepoznavanje, analiziranje i razlikovanje značajki vokalnih, vokalno-instrumentalnih i instrumentalnih djela različitih skladatelja, stilskih razdoblja i žanrova te su usmjereni na kritičku procjenu vrijednosti slušanih skladbi. Nastavni program u obje je godine razdijeljen u tri velike cjeline (vokalna, vokalno-instrumentalna i instrumentalna glazba), što predstavlja tematsku okosnicu poučavanja kod koje je u prvoj godini poučavanja nastavni sadržaj usmjeren na obradu glazbenih vrsta isključivo umjetničke glazbe, dok je druga godina učenja usmjerena na različite vrste glazbe 19. i 20./21. stoljeća (umjetnička, tradicijska, popularna, plesna, jazz...). Elementi i oblici praćenja i vrednovanja učenika su: usvojenost nastavnih sadržaja (usmenim i pisanim načinom), primjena znanja te samostalni rad (seminarski rad, istraživanje, suradnja u nastavi i dr.).

\section{Problemi i perspektive podučavanja u nastavi Glazbene umjetnosti}

Iako nastava Glazbene umjetnosti omogućuje sveobuhvatno glazbeno i kulturno obrazovanje, Kos $(2010,97)$ sugerira da glazbena struka ipak treba podići svijest o potrebi za novim pristupima u poučavanju glazbe s ciljem razvitka novih standarda koji odražavaju potrebe današnjih učenika. Unatoč relativno malobrojnoj suvremenoj glazbenopedagoškoj literaturi i istraživanjima o nastavi Glazbene umjetnosti u Hrvatskoj, u Tablici 8 prikazani su problemi koje glazbeni pedagozi uviđaju u nastavi Glazbene umjetnosti s aspekta učenika i nastavnika, a koji se odnose na pojedina problemska područja. 
Tablica 8. Stavovi glazbenih pedagoga o problemima u nastavi Glazbene umjetnosti u Hrvatskoj (Dobrota, 2016b; Rojko, 2012; Šimunović i Svalina 2015; Škojo, 2013, 2015, 2016; Škojo i Matković, 2016; Vidulin, 2013)

\begin{tabular}{|c|c|c|}
\hline $\begin{array}{l}\text { Problemsko } \\
\text { područje }\end{array}$ & $\mathrm{S}$ aspekta učenika & $\mathrm{S}$ aspekta nastavnika \\
\hline $\begin{array}{c}\text { Nastava Glazbene } \\
\text { umjetnosti }\end{array}$ & $\begin{array}{l}\text { tradicionalna je, opterećujuća, zatvorena, } \\
\text { nefleksibilna i suhoparna; zbog gradiva } \\
\text { koje nije u suglasju s glazbenim prefe- } \\
\text { rencijama učenika javlja se odbojan stav } \\
\text { prema nastavi i nastavnicima Glazbene } \\
\text { umjetnosti; mali postotak učenika prefe- } \\
\text { rira glazbu koja se sluša na nastavi glaz- } \\
\text { be; ne uvažavaju se interesi učenika; ista } \\
\text { »verbalizirana» shema, najčešće bez krea- } \\
\text { tivnosti i uloženoga dodatnog truda koja } \\
\text { se ponavlja tijekom svih četiriju (dviju) } \\
\text { godina gimnazijskoga školovanja }\end{array}$ & $\begin{array}{l}\text { nastava se odvija na tradicionalnim di- } \\
\text { daktičkim temeljima; realizira se rutinski, } \\
\text { prema rasporedu tema utvrđenih u udžbe- } \\
\text { niku; problemi pri ocjenjivanju učenika, } \\
\text { predviđena tri elementa za vrednovanje } \\
\text { tijekom } 35 \text { nastavnih sati godišnje; kva- } \\
\text { litetna nastava glazbe ne može se sažeti } \\
\text { u } 45 \text { minuta }\end{array}$ \\
\hline Nastavni sadržaj & $\begin{array}{l}\text { nezanimljiv; nije kreativan; nema razno- } \\
\text { likih i suvremenih sadržaja; mali posto- } \\
\text { tak učenika izvan nastave sluša glazbu s } \\
\text { CD-a koji su dobili uz udžbenik; udžbe- } \\
\text { nici su nepotrebni; nema mogućnosti za } \\
\text { upoznavanje glazbe koju učenici slušaju } \\
\text { u slobodno vrijeme }\end{array}$ & $\begin{array}{l}\text { previše je opsežan i nedostaje vremena } \\
\text { za kvalitetnu realizaciju; rad po dijakro- } \\
\text { nijskom modelu suhoparan je, monoton } \\
\text { i demotivirajuć; započinje s najmanje } \\
\text { atraktivnom glazbom srednjeg vijeka i } \\
\text { renesanse; raspored nastavnoga sadržaja } \\
\text { utvrđenoga u kronološkom redoslijedu ne } \\
\text { djeluje motivirajuće na učenike }\end{array}$ \\
\hline $\begin{array}{c}\text { Metode i strategije } \\
\text { poučavanja }\end{array}$ & $\begin{array}{l}\text { frontalni oblik; izravno poučavanje; usme- } \\
\text { no izlaganje; samostalno obrađivanje } \\
\text { lekcija i rješavanje zadataka iz udžbeni- } \\
\text { ka; prepisivanje s ploče ili iz udžbenika; } \\
\text { nedovoljno suvremenog pristupa, upora- } \\
\text { be projektnog učenja i igara u nastavi; } \\
\text { verbalizam na štetu glazbenog doživljaja; } \\
\text { premalo socijalnih oblika poučavanja i } \\
\text { individualizacije u nastavi }\end{array}$ & $\begin{array}{l}\text { frontalni oblik; metoda usmenog izlaga- } \\
\text { nja; ista shema predavanja tijekom svih } \\
\text { četiriju (dviju) godina gimnazijskoga } \\
\text { školovanja; nedostatak efikasnih metoda } \\
\text { za uspostavljanje discipline }\end{array}$ \\
\hline Učenici & $\begin{array}{l}\text { nezainteresiranost i nemotiviranost za } \\
\text { nastavne sadržaje i aktivnosti; pasivno } \\
\text { slušanje glazbe na satu; slaba posjećenost } \\
\text { kazališta i koncerata umjetničke glazbe }\end{array}$ & $\begin{array}{l}\text { nesuglasje između programskih sadržaja } \\
\text { i preferencija učenika; učenici nemaju } \\
\text { razvijene sposobnosti za aktivno slušanje } \\
\text { glazbe; izrazito malen interes za klasičnu } \\
\text { glazbu }\end{array}$ \\
\hline Nastavnici & $\begin{array}{l}\text { diktiranje nastavnika i prepričavanje } \\
\text { sadržaja iz udžbenika; nastavnikovo ka- } \\
\text { žnjavanje ispitivanjem; neangažiranost } \\
\text { nastavnika; nastavnici ne prihvaćaju } \\
\text { didaktički pluralizam u smislu kombi- } \\
\text { niranja nastavnih aktivnosti, strategija i } \\
\text { oblika rada }\end{array}$ & $\begin{array}{l}\text { nedostatak motivacije i entuzijazma zbog } \\
\text { istovrsnog načina rada i preopterećenja } \\
\text { uslijed rada na više škola; manjkavo me- } \\
\text { todičko-pedagoško-psihološko obrazova- } \\
\text { nje }\end{array}$ \\
\hline $\begin{array}{c}\text { Uvjeti održavanja } \\
\text { nastave }\end{array}$ & $\begin{array}{l}\text { nedovoljno suvremene nastavne tehno- } \\
\text { logije; nastavnici ne upotrebljavaju raču- } \\
\text { nalne programe niti kao medij kojim se } \\
\text { omogućava aktivno stjecanje znanja, niti } \\
\text { u svrhu oplemenjivanja pojedine nastav- } \\
\text { ne etape, za ponavljanje ili provjeravanje } \\
\text { znanja i sposobnosti }\end{array}$ & $\begin{array}{l}\text { neodgovarajuća oprema i prostori za odr- } \\
\text { žavanje nastave; nedostatak nastavnih } \\
\text { pomagala; nedostatak uporabe infor- } \\
\text { macijsko-komunikacijske tehnologije; } \\
\text { problemi u održavanju discipline; nepoti- } \\
\text { cajna okolina u kojoj se nastavni predmet } \\
\text { nedovoljno cijeni od strane radnih kolega } \\
\text { i učenika }\end{array}$ \\
\hline
\end{tabular}


Prema mišljenju pojedinih istaknutih hrvatskih glazbenih pedagoga očito je da je nastava Glazbene umjetnosti još uvijek u okvirima zatvorenog kurikuluma te da je potrebno osuvremeniti nastavni model koji se permanentno provodi od ustroja gimnazijskog školovanja do danas. Navedeni nedostatci dijakronijskoga modela trebali bi biti osnova za usmjeravanje prema novim kreativnijim mogućnostima podučavanja, osmišljavanju zanimljivijeg i fleksibilnijeg modela koji će u prvom redu motivirati učenike na veću angažiranost i sklonost predmetu, ali i nastavnike da svaki sat realiziraju bolje i inventivnije. U tom smjeru, kako bi se koncepcija nastavnog programa Glazbene umjetnosti prilagodila zahtjevima modernog doba, potrebno je osuvremeniti metode rada i strategije učenja, nastavna sredstva i pomagala te je nužno staviti učenika u fokus nastavnog procesa. Promatranje i uvažavanje učenika kao cjelovite osobe, s njegovim interesima i potrebama načela su kvalitetne škole koja naglašava poštivanje duhovnosti učenika, razvijanje njegove samostalnosti, stjecanje znanja praktičnim radom, učenje na samoj stvari, kooperativno učenje i samoprovjeru uspjeha (Šimunović i Svalina, 2015, 65). Zato bi glazbeni pedagozi trebali težiti ne samo korisnim nego i zanimljivim nastavnim programima jer učenici do srednje škole već prilično formiraju svoje stavove o glazbi, ali i o nastavi glazbe, čime su očekivanja od nastavnog predmeta, odnosno kriteriji glazbenih preferencija, veći. Da bi estetski odgoj i razvoj glazbenoga ukusa učenika putem nastave glazbe bio učinkovitiji, trebalo bi provesti nova akcijska istraživanja na većem uzorku učenika u više različitih srednjoškolskih usmjerenja kroz nekoliko godina i razmotriti mogućnost izbora ili promjene koncepcije nastavnog programa Glazbene umjetnosti koji bi svoje temelje mogao imati u sinkronijskom modelu, ali i znanstvenim istraživanjima glazbenih preferencija. Razlog tome je što je sinkronijski model, ali i razumijevanje uzročno-posljedičnih veza kod glazbenih preferencija učenika usklađeno s aktualnim kurikulumskim načinima provođenja procesa obrazovanja i stjecanja kompetencija. Takav pristup unosi suvremenost u glazbenu nastavu, ali i potreban pluralizam u realizaciji nastave Glazbene umjetnosti koja stremi prema kompetencijama potrebnim modernim učenicima (Škojo i Matković, 2016, 247). Poželjno je i sudjelovanje učenika u kreiranju i predlaganju redoslijeda nastavnog sadržaja. Kod obrade glazbenih vrsta i oblika trebalo bi težiti raznolikosti glazbenih stilskih izričaja jer, ukoliko je glazba atraktivna i adekvatno metodički obrađena, proizaći će i motivacija za daljnje glazbeno podučavanje. Stoga je potrebno izbjeći sav nepo- 
treban i eventualno nezanimljiv sadržaj usmjeren na opsežne povijesne činjenice i korelacije jer nastava Glazbene umjetnosti u svojoj srži ne bi trebala imati isključivo teorijsko proučavanje kronologije povijesti glazbe, već upoznavanje i razumijevanje same glazbe te obrazovanje kritičkog slušatelja glazbe. Kritičko slušanje glazbe, koje se po dosadašnjem modelu učilo kroz upoznavanje isključivo umjetničke glazbe (tzv. recepcijski model), može se razvijati i kroz intenzivnije uvođenje različitih vrsta glazbe (tradicijska, popularna, jazz, etno, interkulturalna glazba, glazba medija, vršnjačka glazba, filmska...) i to tijekom svih četiriju godina gimnazijskog glazbenog obrazovanja. Nadalje, češćim korištenjem aktivnih metoda rada (problemsko i heurističko učenje, suradničko i istraživačko učenje, projektna nastava, gosti u nastavi, e-učenje...) kod učenika bi se trebalo razvijati samostalno shvaćanje skladbi i izražavanje stručnim glazbenim jezikom, dok bi se korištenjem informacijske tehnologije i društvenih mreža trebalo težiti maksimalnom uključivanju glazbe s nastave Glazbene umjetnosti u slobodno vrijeme učenika. Domaći zadatci trebali bi se temeljiti na slušanju i analizi glazbenog djela te na samostalnom otkrivanju novih kvalitetnih glazbenih izričaja (samostalno pronalaženje glazbenih djela u okviru zadanih tema, npr. glazbeno-stilskih izričaja umjetničke, popularne i tradicijske glazbe, dodatno upoznavanje opusa pojedinih skladatelja, kvalitetnih izvođača, obrada umjetničke glazbe u suvremenom izričaju, usporedba različitih interpretacija iste skladbe...), čime bi se razvijao estetski interes i svijest o kvaliteti glazbe koja se obrađuje u nastavi i koju plasiraju mediji ili nameću vršnjaci. Kako učenici svoje preferencije slušanih skladbi najčešće temelje na emocijama i trenutnom raspoloženju, nužno je osvijestiti da su upravo interes, otvorenost i stavovi prema kvalitetnoj, odnosno stavovi prema nekvalitetnoj glazbi ključni za njihovo oblikovanje glazbenog ukusa i razvoj kulturnog identiteta. Također, za razvoj stvaralačke kritike, koja je rezultat izravnog kontakta s glazbom i promišljanja o njoj, potrebno je uključivanje i sudjelovanje učenika u kulturnim aktivnostima škole (i lokalne sredine) te što češći odlasci na koncerte kvalitetne glazbe, čime bi učenici postajali graditelji kulture (eng. culture-builder) vlastite osobnosti, ali i društva (Vidulin, 2014, 72-73). S obzirom na to da glazba zauzima značajan dio slobodnog vremena mladih, poseban značaj treba se posvetiti skrivenom kurikulumu u glazbenom obrazovanju i informalnom obrazovanju jer brojna istraživanja o spolu, rasnoj pripadnosti, socioekonomskom statusu, dobi, narodnosti, vjeri, mjestu prebivališta i subkulturalnom usmjere- 
nju ukazuju da je u nastavi potrebna interakcija tih višeslojnih razlika čime se može postići postmodernističko glazbeno obrazovanje (Abeles i Custodero, 2010). Kako Dobrota (2016b) uočava da se glazbene preferencije formiraju pod utjecajem formalnih, ali i informalnih faktora, u nastavi je poželjno kombinirati formalne $\mathrm{i}$ informalne načine podučavanja i učenja glazbenih sadržaja, što zahtjeva proširivanje nastavnih sadržaja uvođenjem popularne glazbe i glazbi svijeta. Takva znanja učenicima mogu pomoći u generiranju opće i glazbene kulture, kao i pri razumijevanju (glazbene) umjetnosti. Na taj način mogli bi aktivnije pratiti koncertna događanja te se kritički odnositi prema glazbi svih vrsta i stilova, što je u konačnici i svrha (glazbene) kulture: sudjelovati u kulturi zajednice, posjećivati kulturna događanja u kulturnim ustanovama, upoznati i razumjeti djela koja predstavljaju kulturno-umjetnička dostignuća, usvojiti uopćene vrijednosti i kulturne obrasce, oblikovati sustav vrijednosti, moralnu i kulturnu svijest, izraziti svoje ideje, misli, osjećaje, vjerovanja i stavove (Vidulin, 2014, 71-72).

I konačno, ključni čimbenik učinkovitosti nastave Glazbene umjetnosti sam je nastavnik. Njegova stručnost, predanost radu, komunikacijske vještine i kreativnost osnovni su preduvjet razvoja nastave glazbe u smjeru otvorenoga i fleksibilnoga nastavnog procesa (Škojo, 2013, 300). Važnost permanentnog razvoja u smislu proširenja kompetencija, kao i profesionalna uočljivost nastavnika, učenicima daje uzoran primjer predanog rada i osobnog ulaganja u kulturni milje. Kako je izgradnja vlastitog sustava glazbenih i kulturnih vrijednosti od velikog značaja za kvalitetu života ne samo pojedinca nego i društva, potrebno je ostvarivati kontinuiranu suradnju učenika, nastavnika i voditelja odgojno-obrazovnih i kulturnih ustanova i to na tri razine: unutar škole, unutar uže društvene zajednice te unutar lokalnih, regionalnih, državnih i međunarodnih profesionalnih organizacija. Doprinos tome može biti provedba akcijskih istraživanja u nastavi glazbe koja bi svojim rezultatima svakako mogla uočiti aktualne probleme, ali i unaprijediti nastavnu praksu.

\section{Zaključak}

Nastava glazbe u hrvatskim općeobrazovnim srednjim školama trenutno se nalazi u svojevrsnoj dekadenciji. Na to upućuje veliko opadanje interesa učenika za nastavni predmet Glazbene umjetnosti, razdvajanje glazbe koju učenici slušaju u slobodno vrijeme od glazbe koju 
slušaju u školi te uočljiv nizak prag vrijednosnih kriterija slušane glazbe. Činjenica da učenici generalno ne preferiraju glazbu koja se sluša u nastavi Glazbene umjetnosti zasigurno ima negativan učinak ne samo na njihovu percepciju glazbe u svakodnevnom životu nego i na percepciju kvalitetne glazbe uopće, kojoj bi ipak trebao težiti svaki kulturno obrazovani pojedinac. Iz navedenih razloga dovodi se u pitanje učinkovitost estetskog odgoja učenika srednjoškolske populacije koji bi se sustavno trebao razvijati i oblikovati kroz aktualni nastavni program Glazbene umjetnosti. Zbog preopširnosti nastavnoga sadržaja, teorijskog pristupa i modela poučavanja, nastava glazbe ipak ne ostvaruje zadane ciljeve. Uz to, nastavnici uglavnom koriste poznate i iskušane metode rada, a teško uvode suvremene didaktičke metode i oblike. Ipak, zbog svjesnosti navedenih problema, sami upućuju na potrebu za fleksibilnim kombiniranjem nastavnih aktivnosti i nastavnih sadržaja da bi se ostvario poželjni »prirodni« koncepcijski okvir za jedinstvenu nastavu glazbe koja će obuhvaćati cijelu općeobrazovnu vertikalu (Škojo, 2016, 247248). Suvremeno glazbeno obrazovanje zato ne smije ignorirati brojne čimbenike koji mogu utjecati na što veću učinkovitost nastave glazbe u smjeru oblikovanja glazbenoga ukusa učenika. Uvažavanje pluralizma glazbenih pravaca, društveni odnosi, nove tehnologije, mediji, skriveni kurikulum, multikulturalnost, sinkronijski pristup, modeli glazbenih preferencija... sve to omogućuje odmak od tradicionalnog načina podučavanja u nastavi Glazbene umjetnosti, što može imati osvježavajuće i pozitivno djelovanje na razvoj glazbene kulture učenika. Zato je na nastavnicima glazbe da prepoznaju i implementiraju u nastavu ideje i stilove poučavanja koje pronalazimo u suvremenim pedagogijskim trendovima kako bi se u nastavi izbjegla razdioba glazbe na školsku i na svu ostalu glazbu. Uzimajući u obzir Prijedlog Nacionalnog kurikuluma nastavnoga predmeta Glazbena kultura/Glazbena umjetnost (2016) također se uočava organizacija nastave glazbe koja bi trebala proizlaziti iz prirode same glazbe koja je integrativna i interdisciplinarna. Značaj se daje raznolikosti glazbenih stilova, pravaca i žanrova koji se mogu usvajati kronološki (dijakronijski pristup) ili integrativno, savladavanjem različitih glazbenih pojmova (sinkronijski pristup), dok je pored domene Slušanje i upoznavanje glazbe ponuđena i domena Izražavanje glazbom i uz glazbu, uz koju se kao odgojno-obrazovni ishod navodi da učenik može ostvarivati različite glazbene aktivnosti u skladu s vlastitim interesima i sklonostima (pjevanje, sviranje, ples i pokret, stvaralaštvo, uporaba IKT-a). No, neovisno o provedbi Kurikularne reforme 
u Hrvatskoj, potrebno je preispitati kvalitetu nastavne prakse Glazbene umjetnosti u općeobrazovnim srednjim školama te pronaći učinkovite nastavne strategije kako bi učenici mogli razvijati veći interes za slušanje, razumijevanje i preferiranje umjetničke glazbe, a u svim ostalim glazbenim pravcima težiti otkrivanju i slušanju kvalitetnog glazbenog izričaja. Jer samo odgojem i obrazovanjem za postavljanje vrijednosnih kriterija učenici će moći graditi objektivne stavove prema glazbi koja ih okružuje te će tako kao široko obrazovani pojedinci s izgrađenim kulturnim identitetom biti zagovaratelji umjetnosti, ljubitelji kvalitetne glazbe i dionici kulturnog života svoje sredine.

\section{Literatura}

Anić, Vladimir i Goldstein, Ivo (2002), Rječnik stranih riječi, Zagreb: Novi liber. Antonić, Božidar; Senečić, Renata i Šir, Nada (1948), Muzička vježbenica za drugi razred gimnazije i šesti razred sedmogodišnje škole, Zagreb: Nakladni zavod Hrvatske.

Abeles, Harold F. i Custodero, Lori A. (2010), Critical Issues in Music Rducation, New York: Oxford University Press.

Baldwin, Elaine; Longhurst, Brian; Mc Cracken, Scott; Osborn, Miles i Smith, Greg (1999), Introducing Cultural Studies, London: Prentice Hall Europe.

Bray, David (2000), »An examination of GCSE music uptake rates«, British Journal of Music Education, 17, str. 79-89.

Centar za istraživanje tržišta d.o.o (2014), Evaluacija eksperimentalne provedbe strukovnih kurikuluma, Zagreb: Agencija za strukovno obrazovanje i obrazovanje odraslih. Dostupno na: http://www.asoo.hr/UserDocsImages/Evalua cija\%20strukovnih\%20kurikuluma_FINAL_27\%2004\%202014\%20\%5BSa mo\%20za\%20\%C4\%8Ditanje\%5D.pdf [22. 10. 2017.]

Čelar, Antun (1972), Upoznavanje s glazbenim djelom: uvodna skripta iz glazbene umjetnosti za I i II razred gimnazije, Zagreb: Instruktivni centar - Zagreb.

Čelar, Antun i Njirić, Nikša (1987), Stoljeća govore glazbom 1: glazbena kultura u prvom razredu srednjeg obrazovanja, Zagreb: Školska knjiga.

Dobrota, Snježana i Kovačević, Sonja (2007), »Interkulturalni pristup nastavi glazbe«, Pedagogijska istraživanja, 4(1), str. 119-127.

Dobrota, Snježana i Kuščević, Dubravka (2009), »Glazbeni identiteti u kontekstu popularne glazbe«, Godišnjak Titius: godišnjak za interdisciplinarna istraživanja porječja Krke, 2(2), str. 195-206.

Dobrota, Snježana i Reić Ercegovac, Ina (2011), »Stavovi učenika prema glazbi i nastavi glazbene kulture«, Školski vjesnik, 60(2), str. 199-210. 
Dobrota, Snježana (2012a), Uvod u suvremenu glazbenu pedagogiju, Split: Filozofski fakultet Sveučilišta u Splitu.

Dobrota, Snježana (2012b), »Glazba između pedagogije, kulture i jezika«, Pedagogijska istraživanja, 9(1/2), str. 155-162.

Dobrota, Snježana (2012c), Popularna glazba i glazbena nastava. Web predavanje. Dostupno na: https:/www.ffst.unist.hr/images/50013806/SDobrota. Popularna.glazba.i.glazbena.nastava.pdf [28. 4. 2017.]

Dobrota, Snježana i Reić Ercegovac, Ina (2016), Zašto volimo ono što slušamo: glazbeno-pedagoški i psihologijski aspekti glazbenih preferencija, Split: Filozofski fakultet Sveučilišta u Splitu.

Dobrota, Snježana (2016a), »Stavovi studenata prema umjetničkoj glazbi i glazbenoj nastavi«, Školski vjesnik, 65 (tematski broj), str. 33-47.

Dobrota, Snježana (2016b), »Nastava glazbe u kontekstu formalnog i informalnog učenja«, u: Jukić, Renata; Bogatić, Katarina; Gazibara, Senka; Pejaković, Sara; Simel, Sanja i Nagy Varga, Anikó (ur.), Globalne i lokalne perspektive pedagogije, Osijek: Filozofski fakultet u Osijeku, str. 18-27.

Dykema, Peter W. i Gehrkens, Karl W. (2013), »High school music: our educational philosophy«, u: Mark, Michael, M. (ur.), Music Education: Source Readings from Ancient Greece to Today, 4th edition, New York: Taylor \& Francis, str. 73.

Dugandžić, Ivona (2012), Glazbena nastava kao dio estetskog odgoja. Neobjavljeni diplomski rad, Zagreb: Sveučilište u Zagrebu, Muzička akademija i Filozofski fakultet, Odsjek za glazbenu pedagogiju i pedagogiju.

Elliott, David. J. i Silvermann, Marissa (2015), Music Matters: A Philosophy of Music Education, 2nd edition, New York: Oxford University Press.

Gaćina Škalamera, Sonja (2014), »Zakon o pučkim školama i preparandijama u kraljevinama Hrvatskoj i Slavoniji iz 1874. godine«, Anali za povijest odgoja, 13, str. 99-133.

Hargreaves, David J.; Miell, Dorothy E. i MacDonald Raymond A. R. (2005), »How do people communicate using music?«, u: Miell, Dorothy E; MacDonald Raymond A. R. i Hargreaves, David J. (ur.), Musical Communication, Oxford: Oxford University Press, str. 1-25.

Harland, John (2000), Arts Education in Secondary School: Effects and Effectiveness, Slough: NFER. Dostupno na: https://www.nfer.ac.uk/publications/eaj01/eaj01.pdf [27. 3. 2017.]

Izvještaj o pregledu pedagoško-instruktivnog rada odgojno-obrazovnih zadataka $u$ nastavi Glazbene kulture (1986), Đurđevac: CUO »Vilim Galjer«.

Jaklin, Zrinka (2013), Nastava glazbe u gimnaziji. Neobjavljeni diplomski rad, Zagreb: Sveučilište u Zagrebu, Muzička akademija, VIII. Odsjek za glazbenu pedagogiju. 
Katalog obveznih udžbenika i pripadajućih dopunskih nastavnih sredstava za osnovnu školu, gimnazije i srednje strukovne škole, Zagreb: Ministarstvo znanosti i obrazovanja Republike Hrvatske. Dostupno na: https://mzo.hr/hr/rubrike/katalog-udzbenika [5. 10. 2017.]

Kos, Koraljka (1988), Stoljeća govore glazbom 2, Zagreb: Školska knjiga.

Kos, Ronald P. Jr. (2010), »Developing capacity for change: A policy analysis for the Music Education profession«, Arts Education Policy Review, 111(3), str. 97-104. doi: https://doi.org/10.1080/10632911003626903

Krgović, Vesna (2008), Glazbeni susreti 2 - priručnik s CD-om za nastavnikel nastavnice glazbene umjetnosti za II. razred gimnazije, Zagreb: Profil International.

Krgović, Vesna (2016), Nastavni priručnik uz udžbenik Glazbeni susreti 3. vrste, Zagreb: Profil Klett. Dostupno na: https://www.profil-klett.hr/metodicki-kutak [23. 10. 2017.]

Lamont, Alexandra; Hargreaves, David J.; Marshall, NigelA.i Tarrant, Mark (2003), "Young people's music in and out of school«, British Journal of Music Education, 20, str. 229-241. doi: https://doi.org/10.1017/S0265051703005412

LeBlanc, Albert (1982), »An interactive theory of music preference«, Journal of Music Therapy, 19 (1), str. 28-45. doi: https://doi.org/10.1093/jmt/19.1.28

Lučić, Franjo (1927), Elementarna teorija muzike i pjevanja: za pripravni tečaj Kraljevske muzičke akademije zagrebačke (i za srednje škole), Zagreb: St. Kugli.

Lučić, Franjo (1940), Elementarna teorija glazbe i pjevanja: za srednje škole $i$ početnički tečaj glazbenih škola, Zagreb: St. Kugli.

Madden, Karl (2014), »Aesthetic response«, u: Forde Thompson, William (ur.), Music in the social and behavioral sciences: An encyclopedia, Thousand Oaks: Sage Publications, Inc, str. 22-25. doi: http://dx.doi.org/10.4135/9781452283012.n7

Matijević, Milan i Rajić, Višnja (2015), »Metodologije kurikulumskih promjena: nekad i danas«, Konferencija Učiteljskoga fakulteta Sveučilišta u Zagrebu 2015. - Istraživanja paradigmi djetinjstva, odgoja i obrazovanja, str. 635654. Dostupno na:

https://bib.irb.hr/datoteka/759141.matijevi_i_raji_4_simpozij_UFZG2015.pdf [14. 9. 2017.]

Middleton, Richard (1990), Studying Popular Music, Milton Keynes: Open University Press.

Munjiza, Emerik (2006), »Počeci hrvatskog školstva i njegova teorija«, Anali za povijest odgoja, 5, str. 45-63.

Munjiza, Emerik i Lukaš, Mirko (2006), »Pedagoško-psihološko osposobljavanje učitelja u visokoškolskim ustanovama«, Odgojne znanosti, 8(2), str. 361-383. 
Mursell, James L. i Glenn, Mabelle (2013), »The psychology of school music teaching: the aims of school music«, u: Mark, Michael L. (ur.), Music Education: Source Readings from Ancient Greece to Today, 4th Edition, New York: Taylor \& Francis, str. 74.

[MZOS] Ministarstvo znanosti, obrazovanja i sporta RH (2011), Nacionalni okvirni kurikulum za predškolski odgoj i obrazovanje te opće obvezno i srednjoškolsko obrazovanje, Zagreb: Ministarstvo znanosti, obrazovanja i sporta RH. Dostupno na: http://mzos.hr/datoteke/Nacionalni_okvirni_kurikulum.pdf [11. 12. 2016.]

[MZOS] Ministarstvo znanosti, obrazovanja i sporta RH (2013), Strukovni kurikulum za stjecanje kvalifikacije Medijski tehničar, Zagreb: Ministarstvo znanosti, obrazovanja i sporta. Dostupno na: http://www.asoo.hr/UserDocsImages/ Irena\%20novo\%2019-07-2013/K_Medijski\%20tehnicar.pdf [11. 4. 2017.]

Nastavni programi za gimnazije (1994), Zagreb: Glasnik Ministarstva kulture $i$ prosvjete Republike Hrvatske. Dostupno na: http://dokumenti.ncvvo.hr/Nastavni_plan/gimnazije/obvezni/nastavni-program.pdf [19. 4. 2017.]

Nastavni program za gimnazije. Glazbena umjetnost (1999), Zagreb: Glasnik Ministarstva prosvjete i sporta Republike Hrvatske. Dostupno na:

http://dokumenti.ncvvo.hr/Nastavni_plan/gimnazije/obvezni/glazbeni.pdf [23. 8. 2017.]

Nastavni planovi za gimnazije i strukovne škole (2015), Zagreb: Nacionalni centar za vanjsko vrednovanje obrazovanja. Dostupno na: https://www.ncvvo.hr/ nastavni-planovi-i-programi-za-gimnazije-i-strukovne-skole/ [19. 4. 2017.]

Perak-Lovričević, Nataša i Ščedrov Ljiljana (2013), Glazbeni susreti 1., 2., 3. i 4. vrste, Zagreb: Profil Klett.

Previšić, Vlatko (2007), »Pedagogija i metodologija kurikuluma«, u: Previšić, Vlatko (ur.), Kurikulum: teorije-metodologija-sadržaj-struktura, Zagreb: Školska knjiga, str. 15-37.

Prijedlog nacionalnog kurikuluma nastavnoga predmeta Glazbena kultura i Glazbena umjetnost (2016), Zagreb: Ministarstvo znanosti i obrazovanja Republike Hrvatske. Dostupno na: https://mzo.hr/sites/default/files/migrated/glazbena_kultura_glazbena_umjetnost_nakon_strucne_rasprave.pdf [26.10.2017.]

Profil Klett. Dostupno na: https://www.profil-klett.hr/metodicki-kutak.

Robinson, Phillipa (2009), Examining and Defining the Term 'Musical Culture' Stemming from Secondary Curricula. Objavljena disertacija. The University of Melbourne. Dostupno na: https://minerva-access.unimelb.edu.au/bitstream/ handle/11343/35488/264183_Robinson1.pdf?sequence=1 [13. 2. 2017.]

Rojko, Pavel (1996), Metodika nastave glazbe, teorijsko tematski aspekti, Osijek: Sveučilište Josipa Jurja Strossmayera.

Rojko, Pavel (2001), »Povijest glazbe/glazbena umjetnost u glazbenoj školi i gimnaziji«, Tonovi, 37/38, str. 3-18. 
Rojko, Pavel (2005), Metodika glazbene nastave - praksa II. dio: Slušanje glazbe, Zagreb: Jakša Zlatar.

Rojko, Pavel (2012a), Metodika nastave glazbe. Teorijsko tematski aspekti. E-knjiga, Osijek: Sveučilište Josipa Jurja Strossmayera.

Rojko, Pavel (2012b), Glazbenopedagoške teme, Zagreb: Jakša Zlatar.

Rojko, Pavel (2015), »Nacionalni okvirni kurikulum (NOK) i glazbena nastava«, Tonovi, 65, str. 49-76.

Ross, Malcolm (1995), »What's wrong with school music?«, British Journal of Music Education, 12(3), str. 185-201.

doi: https://doi.org/10.1017/S0265051700002692

Ross, Malcolm (1998), »Missing solemnis: Reforming music in schools«, British Journal of Music Education, 15(3), str. 255-262. doi: http://dx.doi.org/10.1017/S0265051700003934

Savez samoupravnih interesnih zajednica usmjerenog obrazovanja SR Hrvatske (1984), »Okvirni obrazovni programi sadržaja struke u prvoj i drugoj godini usmjerenog obrazovanja (za III i IV stupanj), struka: ekonomska, trgovinska, ugostiteljsko-turistička, upravno-pravna«, Delegatske informacije, 1, str. 3, 16,34 .

Savez samoupravnih interesnih zajednica usmjerenog obrazovanja SR Hrvatske (1984), »Okvirni obrazovni programi sadržaja struke u prvoj i drugoj godini usmjerenog obrazovanja (za III i IV stupanj), struka: tehnološka, grafička, geološko-rudarsko-naftna, odgojno-obrazovna, kulturološka«, Delegatske informacije, 4, str. 12-22.

Savez samoupravnih interesnih zajednica usmjerenog obrazovanja SR Hrvatske (1985), »Okvirni obrazovni programi sadržaja struke za treći i četvrti stupanj stručne spreme, struka: prodavač, skladištar«, Delegatske informacije, 12, str. 4.

Savez samoupravnih interesnih zajednica usmjerenog obrazovanja SR Hrvatske (1986), »Okvirni obrazovni programi sadržaja struke za prvi, drugi, treći i četvrti stupanj stručne spreme, struka: poljoprivredna, veterinarska«, Delegatske informacije, $21 / \mathrm{b}$, str. 4.

Savez samoupravnih interesnih zajednica usmjerenog obrazovanja SR Hrvatske (1988), »Okvirni obrazovni programi usmjerenog obrazovanja, struka: kulturno-umjetnička, prirodoslovno-matematička«, Delegatske informacije, 28, str. 3-4, 18, 39-40, 52, 56-58.

Supičić, Ivo (2006), Estetika europske glazbe: povijesno-tematski aspekti, 2. Izdanje, Zagreb: Školska knjiga.

Svalina, Vesna (2015), Kurikulum nastave glazbene kulture i kompetencije učitelja za poučavanje glazbe, Osijek: Sveučilište Josipa Jurja Strossmayera u Osijeku, Fakultet za odgojne i obrazovne znanosti.

Ščedrov, Ljiljana (2000), »Glazbeni susreti 1., 2., 3. i 4. vrste«, Theoria, 2, str. 16. 
Šimunović, Zrinka i Svalina, Vesna (2015), »Suvremenost pojedinih glazbenopedagoških pristupa iz perspektive nastavnika«, u: Balić, Vito i Radica, Davorka (ur.), Zbornik radova $s$ Četvrtog međunarodnog simpozija glazbenih pedagoga, Split: Sveučilište u Splitu, Umjetnička akademija, str. 45-68.

Škojo, Tihana (2010), Sinkronijski model nastave glazbene umjetnosti i njegova usporedba s dijakronijskim modelom. Neobjavljeni magistarski rad, Sveučilište u Zagrebu, Muzička akademija, Odsjek za glazbenu pedagogiju, Filozofski fakultet, Odsjek za pedagogiju.

Škojo, Tihana (2013), »Kreativnost učenika srednjih škola u nastavi umjetničkoga područja«, Život $i$ škola, 29(1), str. 300-316.

Škojo, Tihana (2015a), Didaktičko-metodičko strukturiranje kurikuluma glazbe u općem i obveznom obrazovanju. Neobjavljena disertacija, Zagreb: Filozofski fakultet Sveučilišta u Zagrebu.

Škojo, Tihana (2015b), »Nastava Glazbene umjetnosti u kurikulumu suvremenog odgoja i obrazovanja«, Poučavanje umjetnosti u 21. stoljeću, Zagreb: Učiteljski fakultet Sveučilišta u Zagrebu, str. 213-230.

Škojo, Tihana (2016), »Nastava Glazbene umjetnosti u kontekstu aktivnog učenja«, Školski vjesnik: časopis za pedagogijsku teoriju i praksu, 65(2), str. 229-249.

Škojo, Tihana i Matković, Ana (2016), »Nagovještaj promjena u nastavi glazbene umjetnosti pod okriljem cjelovite kurikularne reforme«, Zbornik radova $s$ Međunarodne znanstvene konferencije Globalne i lokalne perspektive pedagogije, Osijek: Filozofski fakultet u Osijeku, str. 247-258.

Špoljar, Zlatko (1927), Elementarna teorija muzike i pjevanja: za niže razrede srednjih i njima sličnih škola, III. prošireno izdanje, Zagreb: Narodna knjižnica.

Vidulin-Orbanić, Sabina (2008), »Glazbenom umjetnošću prema cjeloživotnom učenju«, Metodički ogledi, 15(1), str. 99-114.

Vidulin-Orbanić, Sabina (2012), »Utjecaj glazbene nastave na (glazbenu) kulturu učenika«, u: Hrvatić, Neven i Klapan Anita (ur.), Pedagogija i kultura, Zagreb: Hrvatsko pedagogijsko društvo, str. 419-430.

Vidulin-Orbanić, Sabina i Duraković, Lada (2012), Metodički aspekti obrade muzikoloških sadržaja: mediji u nastavi glazbe, Pula: Sveučilište Jurja Dobrile u Puli, Odjel za glazbu.

Vidulin, Sabina (2013), »Propitivanje ostvarenja cilja nastave glazbe u kontekstu vremena glazbene hiperprodukcije«, Arti musices: hrvatski muzikološki zbornik, 44(2), str. 201-225.

Vidulin, Sabina (2014), »Prinos glazbene nastave oblikovanju kulturnog identiteta škole «, Napredak, 154(1-2), str. 65-76.

Vidulin, Sabina i Bolić, Maja (2015), »Analiza učeničkih postignuća iz područja Glazbene umjetnosti i kulture u kontekstu Nacionalnog okvirnog kurikuluma«, Život i škola, 61(2), str. 109-123. 
Vukasović, Ante (2001), Pedagogija, Zagreb: Hrvatski katolički zbor »Mi«.

Završki, Josip (1968), Muzička umjetnost: udžbenik za 1.-4. razred gimnazije, Zagreb: Školska knjiga.

Završki, Josip; Njirić, Nikša; Manasteriotti, Višnja; Županović, Lovro (1972), Glazbena umjetnost: udžbenik za gimnazije, IX. nepromijenjeno izdanje, Zagreb: Školska knjiga.

\title{
MUSIC EDUCATION IN CROATIAN GENERAL SECONDARY EDUCATION
}

\author{
Ivana Senjan
}

Pedagogical reforms both in Croatia and abroad during the last twenty years have shown the need to harmonise the educational system with contemporary educational needs and challenges by bringing the student into the center of the teaching process. Despite the suggestions of many music teachers regarding enhancing and modifying existing teaching approaches, music classes in Croatia have kept the same diachronic form since the 1954/1955 school year, based on the chronological study of music history. This brings the traditionally designed curriculum and contemporary educational efforts into conflict. This paper emphasises the importance of music classes to students' aesthetic upbringing and musical culture development, summarises the general properties of music as a school subject, and provides an overview of its retrospective, its current situation, and current issues regarding its teaching. With the aim of more effective musical education for secondary school students, a more contemporary teaching approach is advised, founded on a model that takes advantage of both scientific research and the practical experience of music teachers. This manner of a model would be vital to achieving important changes in the development of music teaching as a legitimate branch of science.

Key words: aesthetic upbringing, music culture, music classes, music taste, music class models 